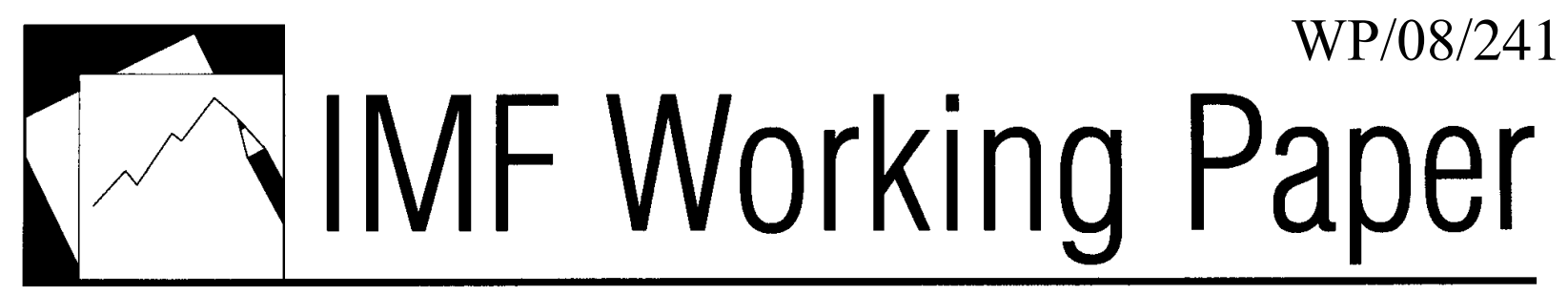

\title{
Household Income As A Determinant of Child Labor and School Enrollment in Brazil: Evidence From A Social Security Reform
}

Irineu Evangelista de Carvalho Filho 



\title{
IMF Working Paper
}

Research Department

\section{Household Income As A Determinant of Child Labor and School Enrollment in Brazil: Evidence From A Social Security Reform}

\author{
Prepared by Irineu Evangelista de Carvalho Filho ${ }^{1}$
}

Authorized for distribution by Gian Maria Milesi-Ferretti

October 2008

\begin{abstract}
This Working Paper should not be reported as representing the views of the IMF. The views expressed in this Working Paper are those of the author(s) and do not necessarily represent those of the IMF or IMF policy. Working Papers describe research in progress by the author(s) and are published to elicit comments and to further debate.

This paper studies the effects of household income on labor participation and school enrollment of children aged 10 to 14 in Brazil using a social security reform as a source of exogenous variation in household income. Estimates imply that the gap between actual and full school enrollment was reduced by 20 percent for girls living in the same household as an elderly benefiting from the reform. Girls' labor participation rates reduced with increased benefit income, but only when benefits were received by a female elderly. Effects on boys' enrollment rates and labor participation were in general smaller and statistically insignificant.
\end{abstract}

JEL Classification Numbers:O12; J13

Keywords: social security reform; child labor; family; school enrollment; old-age benefits, Brazil

Author's E-Mail Address: idecarvalhofilho@imf.org

\footnotetext{
${ }^{1}$ Irineu Evangelista de Carvalho Filho, International Monetary Fund, email: idecarvalhofilho@imf.org
} 


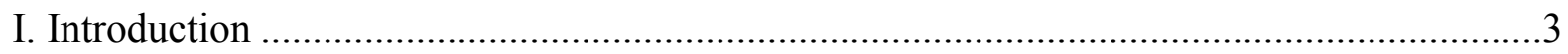

II. Background information about child labor in Brazil ................................................4

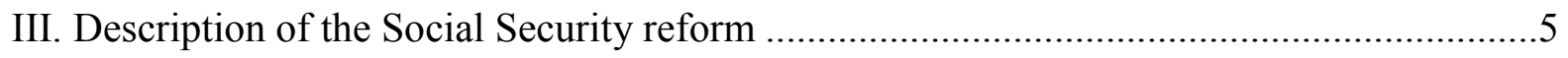

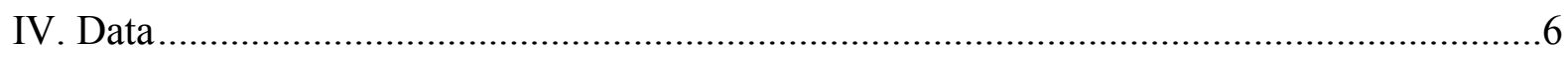

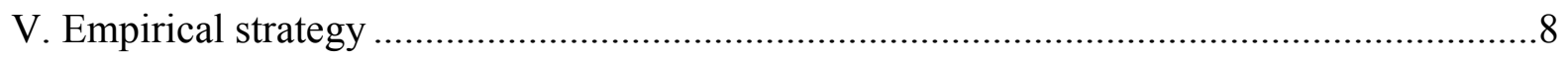

A. The Determinants of Children's Schooling and Labor ...................................... 10

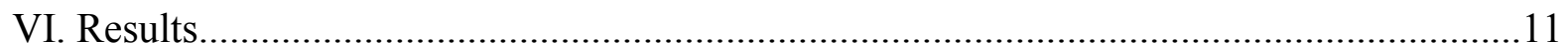

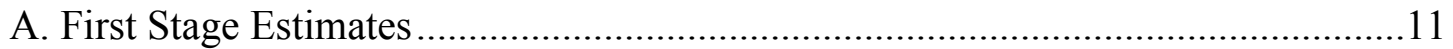

B. Reduced Form Estimates......................................................................... 12

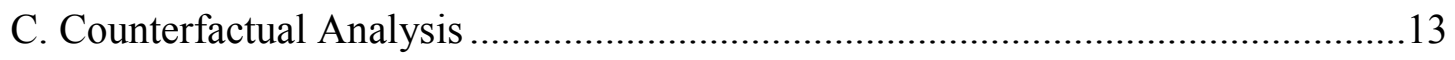

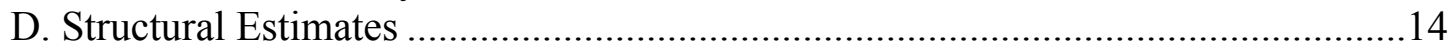

E. Assessing the robustness of the estimates .................................................... 15

VII. Causal Effects or Selection Bias?....................................................................... 17

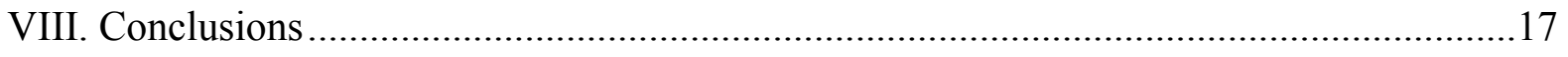

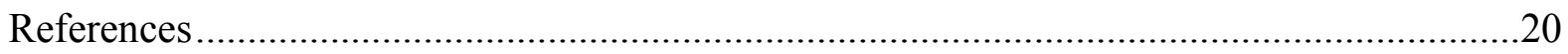

Tables

1. The Work-School Enrollment Statistics of Children 10-14 _....................................24

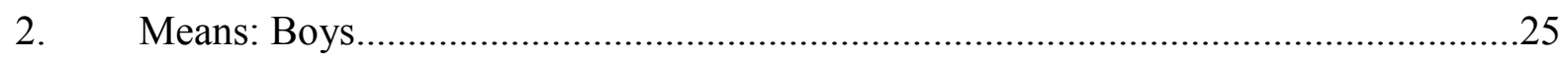

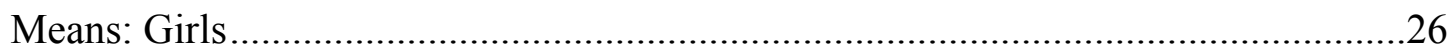

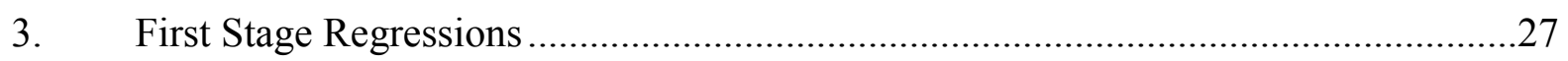

4. Reduced Form Estimates ...............................................................................28

5. Panel 1. Actual and Counterfactual Values fo Treated Group, after the Reform .....................................................................................30

6. Estimates of the Effect of Monthly Benefits. Coefficient is the Estimated

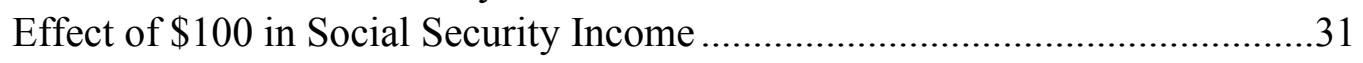

7. Instrumental Variables Estimates of the Effect of Benefits for Different

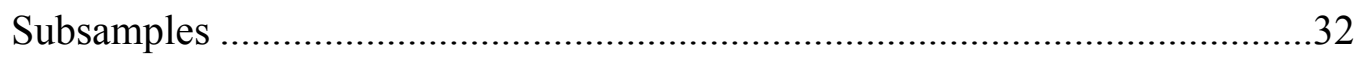

8. Reduced Form Estimates. Has the Reform Changed the Percentage of Elderly Coresiding with Children 10 to 14 ?....

Figures

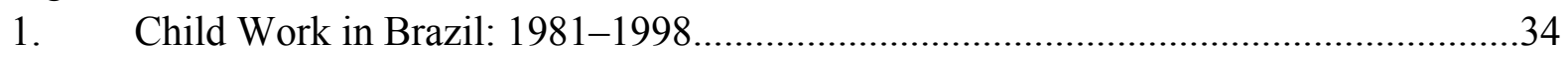

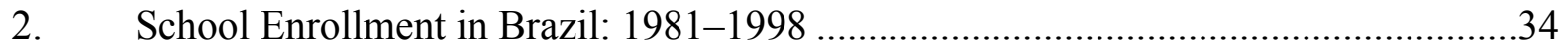




\section{INTRODUCTION}

How strong are income effects on school enrollment and child labor participation in developing countries? That is an important question for the design of policies to enhance the human capital of poor children and reduce inequality in developing countries. If children outcomes improve significantly as incomes rise, targeted transfers to the poor may have long-lasting effects, instead of only boosting the consumption of the poor. On the other hand, if children outcomes are insensitive to rising incomes, efforts to improve the human capital of the poor should focus on other interventions, such as enrollment subsidies, improvements in school quality and teacher pay or construction of new schools.

There is a large (and still expanding) literature on the determinants of child labor and school enrollment decisions in developing countries. ${ }^{1}$ Much of this literature has inquired about the effects of increased incomes on child labor, typically finding that poverty or negative economic shocks are important factors driving children to work. Among other works, Edmonds (2001) finds that seemingly permanent increases in income in Vietnam explain most of the observed decline in child labor; Yang (2007) finds that increases in remittances received from overseas due to favorable exchange rate movements lead to enhanced human capital investment in the Philippines; Duryea, Lam and Levison (2007) find that child labor helps urban Brazilian families to smooth income during temporary unemployment spells of their adult male household head; and Bourguignon et al (2003) and Schultz (2004) find that conditional cash transfer programs such as Bolsa Escola in Brazil and Progresa in Mexico have a positive effect on school enrollment, and the latter also finds a significant reduction in market work. ${ }^{2}$

The unique contribution of this paper is to estimate a pure income effect. It explores exogenous variation in social security income at the household level caused by a reform of Social Security for rural workers in Brazil to estimate the impact of an exogenous increase in income on children's labor participation and school enrollment. This social security reform brought about a reduction in the minimum eligibility age for old-age benefits for rural workers from 65 to 60 for males and 55 for females, the end of a rule that determined that no more than one person per household would be eligible to receive old-age benefits for rural workers, and an increase in the size of benefits from half a minimum wage to one minimum wage. ${ }^{3}$

The paper identifies the effect of benefits on the schooling and labor outcomes of children of ages 10 to 14 by comparing the changes in the outcomes for children living with or without an elderly benefiting from the reform, while controlling for observable variables. Because the eligibility to the old-age program in question is based on age and occupation, the estimates control for, among other things, all interactions between age and occupation of the coresiding adults and survey year (i.e. interactions between age of the coresiding adults and rural occupation; age of the coresiding adults and year; and year 
and rural occupation.) To the extent that trends in the outcomes, controlling for observables, would not differ in the absence of the reform, the effect of the reform on child labor and schooling decisions can be estimated consistently and have a causal interpretation in the sense of Angrist, Imbens and Rubin (1996). ${ }^{4}$ Please note that since the estimates are based on comparing changes over time between groups affected or not by the reform, they are not affected by unobserved factors such as tastes for human capital investments) that might be correlated with occupational choice.

The empirical strategy of this paper overcomes problems common to the previous literature: omitted variable bias and measurement error in income variables. Crosssectional studies relating child labor and household income are not able to identify the pure effect of income from the effects of unobserved characteristics that may be correlated with income. For instance, child labor and school enrollment may be correlated with household income because dynasties with more patience, greater ability or a stronger taste for education will have adults with higher education levels and also higher income. In that case, the cross-sectional relationship between household income and child labor is not informative of the likely effect of policies that transfer income to families with children, because it overestimates the effects of income transfers to poor families on children' labor participation and school enrollment decisions. On the other hand, classical measurement error problems may generate downward bias in the estimated effect of income on children outcomes - this problem may be particularly relevant when variables correlated with income, such as family background and community characteristics, are included in the regression.

This paper also explores the possibility that income received by females generates different outcomes as income received by males. In agreement with Thomas, Schoeni and Strauss (1996) and Duflo (1999), I find that girls' outcomes are more sensitive to benefits received by other females than by males living in the same household. Point estimates suggest that male benefits play a similar role for boys, but standard errors were typically large in the regressions for boys outcomes.

Section I presents background information about child labor in Brazil. Section II presents the empirical strategy. Section III describes the data used in the empirical sections. Section IV presents the regression results. Section V examines the possibility that selection biases are driving the results instead of causal effects, finding reassuring evidence in favor of a causal interpretation. Section VI concludes.

\section{BACKGROUND INFORMATION ABOUT CHILD LABOR IN BRAZIL}

Brazil has one of Latin America's highest rates of child labor force participation. In 1995, when participation rates for children 10-14 in Latin America and Caribbean (LAC) were 9.8 percent, the figures for Brazil were as high as 16 percent. ${ }^{5}$ This backwardness relative to LAC averages has persisted over decades: in 1950, when the participation rate was 
19.4 percent for the LAC average, Brazil lagged behind with a 23.5 percent participation rate. However, since the early nineties, there has been a slow downward trend in labor force participation for boys and girls aged 12 to 14, and an apparently flat profile over time for children aged 10 and 11 (Figure 1).

The majority of Brazilian child laborers work in agriculture activities. ${ }^{6}$ While only 24 percent of youths 10-24 are employed in agriculture, 69 percent of the work force aged 10-11 and 55 percent of the work force aged 12-14 are in that sector (IBGE, 1997). Therefore, effective policies to reduce child labor ought to change the incentives and constraints faced by rural families.

The mirror image of Brazil's high child labor rates of children is a dismal educational record (for a collection of papers on education and income inequality in Brazil, see Birdsall and Sabot, 1996). For instance, Behrman and Schneider (1996) find that secondary school enrollment rates in Brazil are respectively 7.7 percent and 16.4 percent below their "expected values" for females and males after conditioning on income levels and measures of schooling cost. Figure 2 shows the time series of school enrollment rates for children 10 to 14. Enrollment rates for girls are in general higher than for boys; enrollment rates increased for all ages during the nineties, but more sharply during the nineties for the older children (12 to 14 year olds); the opposing trends in child work and school enrollment for those age groups illustrate how those two activities compete for children's time.

Table 1 shows there was an increase of 2.1 percentage points in the proportion of children 10-14 going to school and not working between 1989 and 1993. There was also an increase of 3.4 percentage points in the proportion of children going to school and also working, for a total increase of 5.5 percentage points in the proportion of children going to school. During that period, while the proportion of children working remained constant, there was an increase in the enrollment rates of working children from 28 percent in 1989 to 46 percent in 1993.

Finally, the institutional environment is somewhat at odds with the observed outcomes. ${ }^{7}$ Schooling is compulsory in Brazil up to age 14 or completion of the eighth grade. Public schools are free. Moreover, they provide free meals. Work is only allowed for children 14 and older, with apprenticeship available at age 12 . Hazardous activities are only available for youths older than 18, and for some activities, older than 21. Starting in 1996, the federal government instituted the Child Labor Eradication Program (PETI) with a pilot program in the charcoal producing region of the state of Mato Grosso do Sul. By 1999, this program was expanded to eight other states. ${ }^{8}$

\section{DeSCRIPTION OF THE SOCIAL SECURITY REFORM}

The Brazilian social security reform of 1991 provides a unique opportunity to study the effect of exogenous changes in income on household economic choices, such as 
elderly labor participation, human capital investments on children or marriage and living arrangements of the elderly. Because this reform provides a source of exogenous variation in benefits that is not correlated with a family's demand for human capital investments or disutility from child work, it can be used to identify the effect of exogenous pure income transfers on children outcomes, such as school enrollment and labor participations measures.

This reform reduced the minimum eligibility age for rural old-age benefits for men from 65 to 60 , increased the minimum benefit paid to rural old-age beneficiaries from 50 percent to 100 percent of the minimum wage, extended old-age benefits to female rural workers who were not heads of households (thereby extending the benefits to the elderly wives of rural workers previously uncovered), and reduced the age at which women qualified for benefits from 65 to 55. Because old-age benefits for rural workers are not subject to either an earnings test or retirement requirement, once a rural worker reaches the minimum eligibility age, there is no gain in delaying filing the application for old-age benefits. The only requirement is to provide the documental evidence for his or her claim to eligibility (for a more detailed discussion, see de Carvalho Filho, 2000A or 2007).

The timing of the reform can be summarized as follows: In 1988, the Constitutional change was passed and more informed workers became aware of the future changes yet to be implemented. Immediately after July 1991, when the ordinary law (Lei \#8212/8213) was passed, benefit payments to rural beneficiaries of old-age pensions increased automatically in general from 50 to 100 percent of the minimum wage, and newly eligible rural workers (e.g. 60 to 64 year old males) began to apply for benefits. By September 1992, the month of reference of the 1992 household survey used in this paper, take-up of new benefits was still incomplete, either for bureaucratic reasons or because of delays in the spread of information. Finally, by September 1993, the month of reference of the 1993 survey, almost all of the take-up process had been completed and newly eligible workers were already receiving their benefits.

\section{DATA}

I use the Pesquisa Nacional por Amostra de Domicilios, or PNAD, to make inferences about the labor participation and school enrollment outcomes of 10 to 14 year old children. The PNAD is an annual household survey, with sample size equal to 1/500 of the Brazilian population (about 100,000 households), designed to produce a picture of the living conditions and economic life of the Brazilian population, rural and urban. For every individual, I observe characteristics such as age, race, education, school enrollment, income from different sources, housing and living arrangements, family structure, work, fertility, migration and other topics. I observe various measures of labor supply, including hours of work, labor force non-participation and earnings. 
Work related questions are asked about all individuals over 10 years old. Hence the definition of child labor in this paper is restricted to children 10 or older. For the upper limit, I use 14 - in concordance with the ILO definition of child labor. Age 14 is also the minimum age for legal work in Brazil.

The empirical exercise will use data for the years 1989, 1990, 1992 and 1993. The PNAD survey was not carried out in 1991. The reform was in effect during the two latest years, 1992 and 1993. Data for years previous to 1989 may bring confounding factors because 1988 was a year of major changes in labor regulations due to the promulgation of the Constitution of 1988. The PNAD survey was not carried out in 1994. From 1995 on, there may have been changes in the institutional background (e.g. introduction of the PETI program in 1996), therefore I focus on the data up to 1993.

For the survey years 1989, 1990, 1992 and 1993 there are 133,385 observations for children 10 to 14 years old. Of those, I exclude 804 or 0.6 percent of the observations those are the children who are head of household or spouse of a head of household, boarders, domestic employees or children of domestic employees. The remaining 132,581 observations are the children who are siblings or related to the head of the household or are "aggregated" to the head's family, and will constitute the sample used in the empirical analysis of this paper.

The PNAD classifies social security benefits into two broad categories: aposentadorias, which comprise disability, old age and length of service benefits, and pensões, which comprise military and survivors' income maintenance benefits. In this paper benefits denote the category aposentadoria in the PNAD survey.

The outcomes analyzed in this paper were chosen in order to capture different dimensions of children's work and schooling choices. "Enrolled in school" measures school enrollment. "Worked in reference week?" and "Worked in reference week for pay?" are binary variables capturing children's labor force participation and also whether children are working for pay - rather than working without pay in a family farm or small business. ${ }^{9}$ The concept of work used at the PNAD comprises work for pay, unpaid work such as supporting another member of the household at his job and production for one's own consumption, but does not include household chores or taking care of younger children. "Total hours per week, all jobs" measures the time intensity of children's labor. In the 1989 and 1990 surveys, hours worked by unpaid workers were less than 15 per week were coded as zero. To ensure consistency, hours of unpaid workers below 15 per week are recoded to zero in the 1992 and 1993 surveys. ${ }^{10}$ All the benefits values are measured in Reais of 1997 (in 1997, R\$0.96=US\$1.00), using the deflator derived by Ferreira and Paes de Barros, 1999.

Table 2 presents the means of some of the variables used in this paper, by gender. The sample is divided into treatment and not-treatment groups, where the former denotes the 
households with at least one elderly who potentially benefited from the reform, based on his or her age, gender and rural location or occupation (i.e. males over 60 years old with a rural occupation; females over 55 years old with a rural occupation or location), and the latter are all other children.

A cursory look at the group means confirms that the reform increased the benefits accruing to the treatment households. For treatment boys, i.e. those boys living with an elderly potentially benefiting from the reform, the average total benefits increased from $\mathrm{R} \$ 75.4$ before to $\mathrm{R} \$ 209.6$ after the reform. On the other hand, total benefits accruing to the not-treatment households remained roughly constant, with a small increase from $\mathrm{R} \$ 53.1$ before to $\mathrm{R} \$ 62.0$ after the reform. The difference between the change in total benefits for treatment and not-treatment boys, i.e. the difference in differences for total benefits, was $\mathrm{R} \$ 125.3$ and highly significant (likewise for girls). In terms of relative magnitudes, the share of benefits in total household income remained constant at about 5 percent for the not treatment households, but it increased from about 20 percent to 37 percent for the treatment households.

Table 2 also provides a first look at the effects of the reform on children outcomes. The difference-in-differences for boys enrollment rates and labor outcomes are all insignificant, suggesting that boys outcomes are not sensitive to increases in benefits or any sensitivity is conditional on other characteristics not controlled for in this simple comparison of means. On the other hand, the difference-in-differences for girls' school enrollment is large (5.4 percentage points) and statistically significant; and the effect on their labor variables is ambiguous - there was a small relative increase in work, but a small relative decrease in work for pay.

For both boys and girls, however, there were significant differences in the changes over time of some variables across the treatment and not-treatment group (among them, the number of children 0 to 4 and 5 to 9). Hence the not-treatment group is not suitable as a control group for the treatment group. To overcome this hurdle, the empirical strategy delineated in the following section is based on conditioning in the first and second level interactions between household composition variables, rural location or occupation measures, and time. Finally, I address the issues that arise from the possibility of changes in household composition due to the reform on section VI.

\section{EMPIRICAL STRATEGY}

The use of variation in household social security income to identify the effect of exogenous income on child work and school enrollment requires adequate control for the effects of living with an elderly person unrelated to old-age benefits. Children who coreside with an elderly person are likely to differ from other children for several reasons. Presence of an elderly person may be correlated with unobservable characteristics (e.g. elderly people testify for the importance of patience and investment 
in human capital, or children from older parents are raised in a different manner than other children). Therefore, from one single cross-section, one cannot identify the effects of non-labor income coming from old-age benefits from the effects of the presence of an elderly person that are not related to the benefits elderly receive.

An exogenous reform in social security, however, allows us to separate the effects of benefits from the effects related to the presence of an elderly person. ${ }^{11}$ Because the reform affects some children but not others, I identify the effects of the reform from the time difference in the outcomes of children potentially affected or not by the reform. The cross-sectional pattern of children's labor participation and school enrollment before the reform identifies the effect of coresidence with an elderly person. ${ }^{12}$ The comparison between the cross-sectional patterns of children's outcomes before and after the reform identifies the effect of changes in social security income due to the reform.

In short, I explore the differences between children who coreside with elderly people who are eligible to benefit from the reform and children who do not, before and after the reform, while controlling for other determinants.

The reduced form first-stage equation below sheds light on the empirical strategy I pursue.

$Z=\left(X_{E} \times\right.$ after $) \beta_{E}+X_{E} \gamma_{E}+X_{H} \gamma_{H}+\left(\right.$ year $_{j} \times$ rural $) \theta_{j r}+\left(\right.$ state $_{i} \times$ rural $) \theta_{i r}+u$

In the equation above, $\mathrm{Z}$ is total household receipt of social security benefits, $\mathrm{X}_{\mathrm{H}}$ is a vector of household and personal characteristics such as number of children aged 0-4, education attainment of the head of household, number of household members at different age groups, dummies for race, only son/daughter and others; $X_{E}$ are household characteristics capturing the household exposure to the effects of the social security reform. It includes the counts of males and females by age in each household; dummy for rural location, dummy for year (main effects) and interactions between the counts of males by age and rural occupation, between the count of males by age and year, between the counts of females by age and rural location, and between the counts of females by age and year (first-level interactions). The subset of $X_{E}$ that characterizes the groups affected by the reform enters the equation also interacted with a post-reform dummy. Year dummies interacted with rural area dummies control for time trends in children outcomes that are not due to increases in incomes for households where an elderly is present. State dummies interacted with rural area dummies control for fixed effects reflecting the historical differences in child labor within states across rural and urban areas.

The variables in the first term of the right hand side of equation (1), i.e., the interactions between variables $X_{\mathrm{E}}$ and after are the excluded variables from the structural form equations, where $\mathrm{Y}$ is an outcome of interest, such as school enrollment or labor 
participation and the parameter of interest is the sensitivity of that outcome to social security income $(Z)$ :

$Y=Z \beta++X_{E} \hat{\gamma}_{E}+X_{H} \hat{\gamma}_{H}+\left(\right.$ year $_{j} \times$ rural $) \hat{\theta}_{j r}+\left(\right.$ state $_{i} \times$ rural $) \hat{\theta}_{i r}+u$

In other words, I identify $\beta$, the effect of social security income on the outcome variable $\mathrm{Y}$, using interactions between post-reform dummies with variables measuring a household exposure to the effects of the reform. Therefore, the key to our identification strategy is constancy in the effects of household structure and personal characteristics across the time period under study.

The reduced form equation (1) can also be used for counterfactual analysis. Under the assumptions used for IV estimation, counterfactual outcomes can be constructed from the reduced form equation for the outcome variables, disregarding the term with the variables that are excluded from the structural form equation:

$\hat{Y}_{\text {counterfactual }}=X_{E} \hat{\gamma}_{E}^{Y}+X_{H} \hat{\gamma}_{H}^{Y}+\left(\right.$ year $_{j} \times$ rural $) \hat{\theta}_{j r}^{Y}+\left(\right.$ state $_{i} \times$ rural $) \hat{\theta}_{i r}^{Y}$

The strategy of using exogenous changes in old-age benefits to make inferences about child labor depends on absence of children self-selection into living with the elderly as a function of elderly eligibility to benefits. Concerns about self-selection are addressed in section VI below.

\section{A. The Determinants of Children's Schooling and Labor}

The determinants of child work and school enrollment are own child's characteristics, siblings' availability and their characteristics, parent characteristics, and household characteristics.

Children's age and gender are expected to affect their work and schooling. Beyond a certain age, the older the child, the more likely he or she works. Girls often substitute for their mothers in household chores and child care activities, particularly when the mother supplies work in the market (Connelly, DeGraff and Levison, 1996). To the extent that benefits reduce the market activities of older women in the household, girls might substitute time at school for time doing household chores or child care activities. Please note, childcare and household chores are not counted as work for the PNAD survey. As a consequence, one would expect only a minor effect of the reform on girls labor market activities.

Several variables control for the effects of family composition. ${ }^{13}$ The number of children in the household in the age groups 0 to 4 and 5 to 9 proxies for the demand for childcare services. The presence of younger siblings increases the demand for childcare services, probably imposing a burden on girls' school attainment and enrollment. 
Dummies for oldest child overall, oldest daughter and oldest son capture older child effects - oldest daughters may carry a disproportionately large burden in household chores, and oldest sons may be picked by fathers to follow their tracks by learning their jobs as apprentices. Other family and birth order effects are captured by dummies for second and third oldest children, for the youngest child, and for only children, and the number of children in the family.

Parents' education also affects child labor and school enrollment through several channels. The education of parents affects their wage rates positively, proxies for their attitudes towards education, and also may be an input complementary to schooling on their children's human capital production function. All those factors suggest that higher parent education increases school enrollment and reduces child labor.

The number of adults (defined as those aged 20 years or older) in the household is a measure of a household potential income. The number of adults working at rural jobs is a measure of the household's engagement in rural activities, which seem to be the main occupation for child workers.

Cost and quality of schooling also affect children's time use. Direct pecuniary costs of schooling are likely to be negligible since public education up to the high school level is for free in Brazil. However, indirect costs such as foregone income and non-pecuniary costs such as travel time from home to school are likely to be important factors. Because primary education is mostly funded at the state level, and because non-pecuniary costs, indirect costs of schooling and school quality are likely to vary within each state (Behrman and Birdsall, 1983) along a rural-urban dimension, I use interactions of state and rural location to control for those effects.

Other controls are dummies for the different racial categories in the Brazilian survey instrument, female-headed household, presence of the head's spouse and metropolitan area.

\section{Results}

\section{A. First Stage Estimates}

The first stage regression relates the endogenous variable, benefits in the household, to all variables that belong to the structural equation Error! Reference source not found.) plus the variables that will be excluded from that equation and used as instruments for the benefits variable.

The coefficients reported in the top four rows in Table 3 confirm that the excluded variables based on characteristics of the reform in social security benefits are strong

predictors of benefits and jointly significant at any significance level. ${ }^{14}$ For instance, the results reported in column (1) show that rural households with one female aged 55-64 
received monthly benefits about $\mathrm{R} \$ 41$ higher in 1992-93 than they did in 1989-90. ${ }^{15}$ Conversely, households with one male rural worker aged 60-64 receive monthly benefits $\mathrm{R} \$ 54$ higher in 1992-93 than they did in 1989-90. Those increases in benefits correspond to the effect of reductions in the minimum eligibility age for rural old-age benefits for workers of both genders. The reform also increased the benefits from 50 percent to 100 percent of the minimum wage for those already eligible, benefits increased $\mathrm{R} \$ 46$ for rural households with one unmarried female aged 65 or older saw an increase of benefits; and $\mathrm{R} \$ 52$ for households with a male 65 or older with a rural occupation. The patterns of the coefficients on columns (2)-(3) also reproduce the expected effect of the reform on male and female benefits, but the excluded instruments are more strongly significant in the regression for female benefits. Table 3 also shows that benefits increase with education levels of the head and his or her spouse.

\section{B. Reduced Form Estimates}

In the reduced form equations, the excluded instruments, which are interactions between time after the reform and indicators for belonging to groups affected by the reform, substitute for the benefits variables.

Reduced form estimates are reported in Table 4. The top four explanatory variables correspond to the excluded instruments, i.e. they are indicators of exposure to the reform interacted with the period after the reform. For each of the equations estimated, I calculate F-tests for joint significance of the excluded instruments, and report their pvalues in bold. The set of excluded instruments was found to be statistically significant at the 5 percent level in the equations for girls' work in the reference week; and at the 10 percent level in the equations for boys' work in the reference week and girls' school enrollment.

Estimates for school enrollment are reported in columns (1)-(2). As expected, living in a rural location has a large negative effect on school enrollment for both boys and girls. Being the son or daughter of the head, or even being related to the head of the household, as compared to being "aggregated" to the household has a large positive effect on school enrollment for both boys and girls. The presence of children aged 0-4 reduces boys' and girls' school enrollment by 4.3 percent and 4.7 percent respectively. Being the oldest child in the family increases, ceteris paribus, girls school enrollment by 2.7 percent but there is no such effect for boys. The number of children in the family has a small but statistically significant positive effect for girls. There is a large positive effect of a female head on the probability of school enrollment for both boys and girls (2.6 and 2.9 percentage points, respectively). And last but not least, the education of the head and the head's spouse have a large and significant effect: the effect on school enrollment: living in a household whose head has more than 4 years of schooling (instead of no schooling) is 12.3 and 8.3 percentage points for boys and girls respectively. A similar gradient is found for the education level of the head's spouse. 
Estimates for "worked in the week of reference" are reported in columns (3)-(4). The presence of one child aged 0-4 and 5-9 increases boys' participation by 1.9 and 1.4 percentage points respectively, but has no effect on the work of girls. Boys and girls' labor participation are higher when they are the oldest child in the household by 5.2 and 2.9 percentage points respectively. As a mirror image of the results for school enrollment, the more educated are the head and the spouse of head, the smaller is the labor force participation of boys and girls. As referred above, the only equation where the excluded instruments were jointly significant at the 5 percent level was girls" "worked in the week of reference". The reduced form estimates show a 5.9 percentage points reduction in that variable for each coresiding female aged 55-64 in a rural location after the reform; and a 5.6 percentage points increase for each coresiding male aged 65 or older with a rural occupation. On the other hand, the presence of a rural male over 65 after the reform is associated with a 8.4 percent drop in boys' work.

The results for work for pay (columns 5-6) and hours of work (columns 7-8) show the similar patterns as the results for "worked in the week of reference?" reported above.

\section{Counterfactual Analysis}

From the reduced form estimates, one can construct a counterfactual in order to evaluate the impact of the reform on the outcomes of interest for the sub-population that was affected by the reform. The effect of the reform can be evaluated from the difference between the actual outcomes for the sub-population of interest and the predicted outcome if no reform had occurred. This counterfactual can be obtained by subtracting the effect of the excluded variables (interactions between post-reform dummies and characteristics of the elderly in the household) from the fitted values from the reduced form equation.

The counterfactual analysis finds that the reform had significant effects on school enrollment for boys and girls, with a particularly large effect for girls. For girls, the difference between counterfactual and actual values is 5.1 percentage points (73.9 to 79.0 percentage points) - a little less than one-fifth of the difference between counterfactual and 100 percent enrollments. The effect of the reform for boys was more modest: an increase of 3.2 percentage points, corresponding to a smaller fraction of the gap between counterfactual and full enrollment rates, and only marginally significant (based on bootstrapped standard errors). While the estimated increase in school enrollment, for girls in particular, is sizeable, it highlights the limitations of pure transfer programs as means to increase enrollment rates. The bottom panel of Table 5 shows that the combined increase in girls and boys enrollment was about 73,000 children girls out of about 1.75 million children living with an elderly benefiting from the reform. The increase in benefits accruing to the households with children was about $\mathrm{R} \$ 40.1$ Millions per month. The combination of those two figures yields a suggestive cost per additionally enrolled child of $\mathrm{R} \$ 548$ per month (compare it to the average total benefit accruing to households with children of R\$62, Table 2). 
For the variable measuring work in the reference week, the counterfactual exercise estimates a decrease of 4.4 percentage points, from 54.7 to 50.4 percentage points, for boys, and no change for girls. The reduction in work for boys, however, is not evident as regards market work for pay - for both boys and girls, there is no significant change. These results suggest that any effects on boys work was through a reduction in unpaid work, usually performed at a family own farm or establishment. It is noteworthy that the point estimate for girls of 1.5 percentage point reduction in work for pay represents a drop of about 20 percent in their rate of market work relative to the counterfactual. The results for hours of work show no significant reduction relative to the counterfactual for both boys and girls.

\section{Structural Estimates}

Table 6 presents the OLS and the IV estimates for the parameter $\beta$ of the structural form equation (2) in a sample of children 10 to 14 year old. Because I divided the benefit amounts by 100 , the coefficients are to be interpreted as the effect of an increase in benefits of R\$100 in Reais of 1997.

Firstly, for all outcomes, IV estimates are much larger than OLS estimates in absolute values. For instance, OLS estimates suggest that the effect of R $\$ 100$ of female benefits on girls' school enrollment is 0.02 percent - against 6.3 percent implied by IV estimates. As in Angrist and Imbens (1995) and Kling (2000), IV estimates based on the reform rules should be interpreted as the weighted average of causal effects for the subgroup affected by the reform. Because the group affected by the reform - children living in households with a rural elderly - is particularly interesting due to high coincidence of rural activities and poverty, the IV estimates are informative of the likely effects of income transfers policies on the outcomes of a relevant group.

Estimates for the effects on school enrollment show differential responses for boys and girls. An increase in benefits of R $\$ 100$ increases girls' school enrollment by 6.3 percentage points (significant at the 5 percent level) but has a smaller effect, 2.9 percentage points, and wider confidence intervals for boys. There are some suggestive results on gender differences, in line with previous literature on violations of the unitary model of the household found in Brazilian data (Thomas, 1990, Thomas, Schoeni and Strauss, 1996): for a given benefit receiver gender, there is a more positive effect on the school enrollment of children of the same gender as the receiver; whereas for each child gender, benefits also have a more positive effect when received by an adult of the same gender. However, as regards school enrollment, those differences are not statistically significant.

For labor participation variables, estimates imply that an increase of $\mathrm{R} \$ 100$ in total benefits in the household reduces the probability of having "worked in the reference week" by 6.3 percentage points for boys and about zero for girls, but standard errors are 
very wide. However, when one compares the effect of male and female benefits on girls, one can find large differences in the effects. The gender of the benefit recipient matters for girls: the coefficient for female benefits is -11.7 percentage points and for male benefits is 4.6 percentage points, and the p-value for a F-test that those effects are equal is 0.0634 .

When one considers only market work ("worked in reference week for pay"), the IV estimates have wide standard errors, and only the -10.2 percentage points effect of female benefits on girls is significant at the 10 percent level. Estimates for the effect on work for pay imply that a large part of the reduction of girls' participation due to benefits earned by females is made up of a decrease in girls' participation in the remunerated labor force. Again, the test for equality in the effect of male and female benefits on girls' market work has a p-value of 0.0594 , suggestive that the gender of the benefit receiver matters.

The estimates for hours of work again display gender differentials with boys and girls reducing hours only in response to benefits received by elderly of the same gender. However, one can only reject the equality in the effect of male and female benefits at the 10 percent level ( $p$-value of 0.1037 ) as standard errors are wide.

\section{E. Assessing the robustness of the estimates}

Table 7 reports IV estimates of the effect of benefits on school enrollment for different subsamples. In this table, columns (1) and (3) report the coefficient on total benefits for respectively boys and girls. Columns (2a)-(2b) and (4a)-(4b) report the coefficients on male and female benefits for respectively boys and girls. Row (1) reproduces the results for the full sample, which is as reported in Table 6.

In row (2), it is clear that benefits have no effect on school enrollment of the younger children, aged 10-11. On the other hand, row (3) shows there are larger effects of benefits on outcomes of the older children, aged 12-14. It is noteworthy that the effect of female benefits on girls school enrollment is as large as 0.198 (the mean of the dependent variable is 0.689 ).

To address the concern that younger households might be different in ways not accounted by the observable variables, I create a mature subsample composed by all the households with at least one person older than 50, which represents 30.6 percent of the full sample. The results reported on row (4) are not significantly different from the full sample.

Concerns that the presence of urban children - in many ways exposed to different circumstances than rural children living in rural locations - in the control group motivate the estimates reported in row (5). When the sample is restricted to children living in a rural location (28.1 percent of the full sample), the standard errors on the boys' regression turn wider, and the results for girls are attenuated and lose statistical significance. 
Row (6) presents results based on a different definition of the post-reform period, substituting 1995 and 1997 for 1992 and 1993 as the relevant post-reform period. By using a later period as post-reform, the estimates are likely affected by changes in the institutional background, such as the PETI program. The results show significant effects of total benefits: enrollment rates for boys increased 4.1 percentage points for boys and 3.4 percentage points for girls. Those estimates are statistically equal to the baseline estimates in this paper. The coefficients for male and female benefits on boys' enrollment rates are smaller and estimated more precisely.

The poor northeastern region of Brazil is home for 35 percent of Brazilian children aged 10 to 14. Large marginal effects might be found in that region, because elderly benefits represent a larger share of average household earnings than elsewhere. On the other hand, public schools of poor quality are prevalent in that region (see Behrman and Birdsall (1983)). The estimates based on the northeastern sub-sample, reported in row (7), have wide standard errors, but the effect of total, male and female benefits on girls' enrollment is positive and large in absolute terms.

Parents' education is a well-known determinant of school attainment: more educated parents allegedly value education more highly than parents with no schooling. A pessimist would argue that income transfers to the poor might not increase school enrollment by itself because the demand for education of the least educated poor is income inelastic. Estimates based on the subsample of households whose head had less than 4 years of schooling, reported in row (8), show that both male and female benefits increase school enrollment for girls, with point estimates not different than for the full sample, albeit estimates are not statistically significant. For boys, the coefficient on total benefits is larger than the one for the full sample, but again not significant.

Previous work has shown that Brazilian teenage girls often spend time caring for younger siblings (e.g. Connelly, DeGraff and Levison, 1996, Kruger and Berthelon, 2007), possibly in detriment of their human capital accumulation. Estimates based on the subsample with presence of children younger than 5 in the household, reported in row (9), confirm that finding: the effect of benefits on girls' school enrollment shrinks or even reverts to negative when young children are present in the household. The results suggest that for Brazilian rural girls, when taking care of younger siblings is the alternative to schooling, increases in income caused by the social security reform did not have an effect on school enrollment. Puzzlingly, female benefits are found to decrease the school enrollment of boys with younger siblings. Finally, in row (10), estimates based on the sub-sample with presence of children in the 5 to 9 age group are found to differ little from estimates based on the full sample, which suggests that the bulk of the call on girls to support the care of younger siblings happens when those are younger than 5 . 


\section{Causal EfFects or Selection Bias?}

The identification strategy of this paper depends on children not moving into (or away from) households receiving the new social security benefits, because children moving due to the reform may be systematically different from other children - therefore causing the estimates to be biased due to selection problems. For example, it is plausible that the decision to send a child to live with a grandparent after the increase in benefits might be

correlated with unobserved characteristics such as preference for schooling. ${ }^{16}$

In the absence of panel data, as in Ardington, Case and Hosegood (2007), it is hard to tell how much our estimates of the effect of benefits might be due to selection of children into and out of households. However, the data permits testing the hypothesis that there were changes in the household demographic composition of the elderly as if in response to the increase in benefits. In particular, we can test whether there were changes in the number of children 10 to 14 years old living in the same household as the elderly affected by the reform. In the regressions reported in Table 8, I control for all interactions between age, year and rural location as in the previous regressions, and calculate the effect of becoming eligible to receive benefits or to have benefits doubled on the number of children living with elderly men or women. The results show that there was no significant changes in the number of boys and girls aged 10 to 14 with elderly benefiting from the reform. ${ }^{17}$ This finding provides some reassurance that selection bias plays only a small role in driving the results of this paper, if any. However, the data does not allow us to identify changes in the quality of children coresiding with the elderly.

\section{Conclusions}

This paper used variation in old-age benefits received by rural workers due to a reform in social security benefits to identify the effect of income on labor outcomes and school enrollment of children of ages 10-14 in Brazil. This empirical strategy based on exogenous variation in old-age benefits is adopted because cross-sectional comparisons between income levels and children's outcomes are not able to identify the effect of nonlabor income from the effect of other characteristics that are correlated with income.

The results in this paper imply that old-age benefits have the effect of increasing school enrollment of girls coresiding with old-age beneficiaries, particularly girls ages 12-14 IV estimates imply that $\mathrm{R} \$ 100$ of old-age benefits received by household members increases school enrollment rates of girls by 6.2 percent, with smaller and less precisely estimated effects for boys.

The effects on labor participation show important differences between boys and girls. Point estimates of the effects of benefits on boys' labor participation suggest there were reductions, but standard errors were very wide. On the other hand, girls labor 
participation, particularly on market activities, dropped sharply, but only in response to benefits received by elderly females.

The magnitude of the effect can be interpreted by means of a counterfactual exercise based on reduced form estimates. This counterfactual analysis implies that slightly less than 20 percent of the gap between 100 percent enrollment and counterfactual enrollment rates was closed for girls living with at least an elderly person who benefited from the reform. Labor force participation of boys ("worked in reference week") also seems to have been affected by the reform, with participation rate reducing 8 percent due to the reform, based on the same counterfactual exercise.

Because IV estimates in this paper are based on exogenous variation in benefits, they are informative of the likely effect of policies that redistribute cash to families with children in Brazil. The estimates in this paper imply that cash benefits alone are not a costeffective policy to increase school enrollment or reduce child labor. For instance, $\mathrm{R} \$ 100$ monthly only boosted girls' enrollment rates by 6.2 percentage points and the cost per additional enrolled child was over $\$ 500$ monthly (were such income transfer targeted to increase school enrollment). The same remark is valid for child labor reduction. Therefore, measures such as conditioning the receipt of cash benefits to school attendance, or improvements in enforcement of labor standards are called for as complements to any pure cash transfer program. One example of a program that conditioned the receipt of cash benefits to school attendance is the Progresa program in Mexico (Gomez de Léon, Parker and Hernandez, 1999). ${ }^{18}$

The empirical exercise also uncovered interesting patterns suggestive of tensions between male and female adults over girls' use of time, with consequences for the design of transfer policies. Male benefits reduce boys' labor supply and increase boys' school enrollment more than they do girls' outcomes. Female benefits exhibit the opposite pattern, reducing girls' labor supply and increasing girls' school enrollment by more than they do boys' outcomes. If one considers school enrollment a "good" and labor participation a "bad", then male benefits are "less of a good" for girls. ${ }^{19}$ Also female benefits are "less of a good" for boys. These results are similar to the findings by Duflo (1999) that in South Africa social pensions received by grandmothers benefits granddaughters relatively more than if received by grandfathers, and also highlight the importance of developing a collective view of the household (Browning and Chiappori, 1998).

It is noteworthy that results in this paper differ from the U.S. evidence on the effect of income on children's outcomes, particularly Mayer (1997), which forcefully argues that at the margin money can't buy better outcomes for children, once their basic material needs are met. This is not surprising: many children in Brazil do not have their basic material needs met. ${ }^{20}$ 
Last but not the least, one additional remark about the interpretation of these estimates: the variation in income used in this paper is not correlated with economy-wide income variation. Therefore, the effects of income I estimate do not take into account any change in attitudes or social norms towards schooling and child labor due to rising income levels across the board. As a consequence, the effects I find are likely to be underestimates of the changes in child labor and school enrollment that occur as the overall incomes of LDC countries rise. 


\section{REFERENCES}

Angrist, Joshua, and Guido Imbens, 1995. “Two-Stage Least Squares Estimation of Average Causal Effects in Models with Variable Treatment Intensity, Journal of the American Statistical Association, Vol. 90, pp. 431-42.

Angrist, Joshua, Guido Imbens, and Donald Rubin, 1996, "Identification of Causal Effects Using Instrumental Variables, Journal of the American Statistical Association, Vol. 91, pp. 444-55.

Ardington, Cally, Anne Case, and Victoria Hosegood, 2007, “abor Supply Responses to Large Social Transfers: Longitudinal Evidence from South Africa," NBER Working Paper No. 13442.

Ashagrie, Kebebew, 1993, "Statistics on Child Labor,” Bulletin of Labor Statistics, No. 3.

Baland, Jean Marie, and James A. Robinson, 2000, "Is Child Labor Inefficient? Journal of Political Economy, No. 108, pp. 663-679.

Behrman, Jere and Nancy Birdsall, 1983, "The Quality of Schooling: Quantity Alone is Misleading," American Economic Review, No. 73, pp. 928-46.

Behrman, Jere and Ryan Schneider, 1996, "Where Does Brazil Fit? Schooling Investments in An International Perspective," in Birdsall and Sabot (org.), Opportunity foregone: Education in Brazil.

Bertrand, M., Mullainathan, S., and Miller, D, 2003, "Public Policy and Extended Families: Evidence from Pensions in South Africa," The World Bank Economic Review, No. 17 (1), pp. 27-50.

Bhalotra, Sonia and C. Heady, 2003, "Child Farm Labor: The Wealth Paradox," The World Bank Economic Review, No. 17, pp. 197-227.

Birdsall, Nancy and Richard H. Sabot, 1996, "Opportunity Foregone: Education in Brazil," (Washington, D.C.: Inter-American Development Bank), Johns Hopkins University Press.

Bourguignon, Francois, Francisco H.G. Ferreira, and Philippe G. Leite, 2003, "Conditional Cash Transfers, Schooling, and Child Labor: Micro-Simulating Brazil's Bolsa Escola Program," The World Bank Economic Review, Vol. 17, (2), pp. 229-54. 
Browning, M., and P.A. Chiappori, 1998, "Efficient Intra-Household Allocations: A General Characterization and Empirical Tests, Econometrica, Vol. 66, No. 6, pp. $1241-78$.

Cardoso, Eliana and André Portela Souza, 2004, "The Impact of Cash Transfers on Child Labor and School Attendance in Brazil," Department of Economics, Vanderbilt University, Working Paper No. 04-W07.

de Carvalho Filho, Irineu, 2000A, "Old-Age Benefits and The Labor Supply of Rural Elderly in Brazil," Essays in Development Economics, Dissertation, (Cambridge: MIT).

— 2000B, Elderly Women and Their Living Arrangements in Brazil,” Essays in Development Economics, Dissertation, (Cambridge: MIT).

— , 2007, Old-Age Benefits and Retirement Decisions of Rural Elderly in Brazil, Journal of Development Economics, Vol. 86, pp. 129-146.

Connelly, Rachel, Deborah S. DeGraff, and Deborah Levison, 1996, "Women's Employment and Child Care in Brazil," Economic Development and Cultural Change, Vol. 44, pp. 619-656.

Duflo, Esther, 1999, "Grandmothers and Granddaughters: The Effects of Old Age Pension on Child Health in South Africa," mimeo.

Duryea, Suzanne and M.P. Arends-Kuenning, 2003, "School Attendance, Child Labor, and Local Labor Markets in Urban Brazil," World Development, Vol. 31, pp. $1165-78$.

Duryea, Suzanne, David Lam, and Deborah Levison, 2007, "Effects of Economic Shocks on Children's Employment and Schooling in Brazil, Journal of Development Economics, Vol. 84 (1), pp. 188-214.

Edmonds, Eric, 2001, "Will Child Labor Decline with Improvements in Living Standards? mimeo.

Edmonds, Eric, 2007. Child Labor, in Handbook of Development Economics, Vol. 4. .

Edmonds, Eric, Kristin Mammen, and Douglas Miller, 2005, "Rearranging the Family? Household Composition Responses to Large Pension Receipts," The Journal of Human Resources, Vol. 40, pp. 186-207.

Emerson, Patrick M., and André Portela de Souza, 2000, "Is There A Child Labor Trap? Intergenerational Persistence of Child Labor in Brazil," Economic Development and Cultural Change, (January 2003), Vol. 51, No. 2, pp. 375-98. 
—_ 2007, "Is Child Labor Harmful? The Impact of Starting to Work as a Child on Adult Earnings," mimeo.

Ferreira, Francisco and Ricardo Paes de Barros, 1999, "The Slippery Slope: Explaining the Increase in Extreme Poverty in Urban Brazil, 1976-1996," Departamento de Economia, PUC-Rio Texto para Discussão No. 404.

Gomez de León, José, Susan Parker, and Daniel Hernandez, 1999, "PROGRESA: A New Strategy to Alleviate Poverty in Mexico," Document prepared for Social Policy Conference, The World Bank (June 1999).

IBGE, 1997, “Criancas e Adolescentes: Indicadores Sociais 1997," Rio de Janeiro, Brazil: IBGE.

International Labour Office, 1998. "Child Labour: Targeting the Intolerable," Geneva, Switzerland: ILO.

Kling, Jeffrey, 2000, "Interpreting Instrumental Variables Estimates of the Returns to Schooling,” NBER Working Paper 7989.

Krueger, Alan, 1996, “Observations On International Labor Standards and Trade, NBER Working Paper No. 5632.

Kruger, Diana, 2007, "Coffee Production Effects on Child Labor and Schooling in Rural Brazil," Journal of Development Economics, No. 82, pp. 448-63.

Kruger, Diana and Matias Berthelon, 2007, "Work and Schooling: The Role of Household Activities Among Girls in Brazil," mimeo.

Mayer, Susan E., 1997, “What Money Can’t Buy: Family Income and Children's Life Changes, (Cambridge, MA: Harvard University Press).

Ministério da Previdência Social, 1997, Anuário Estatístico da Previdência.

Pianto, Donald M. and Sergei Soares, 2003, "Use of Survey Design for The Evaluation of Social Programs: The PNAD and The Program for the Eradication of Child Labor in Brazil," mimeo.

Schultz, T. Paul, 2004, School Subsidies for The Poor: Evaluating the Mexican Progresa Poverty Program," Journal of Development Economics, Vol. 74, pp. 199-250.

Shea, John, 2000, "Does Parents' Money Matter? Journal of Public Economics, Vol. 77, pp. $155-84$. 
Thomas, Duncan, 1990, "Intra-Household Resource Allocation: An Inferential Approach," Journal of Human Resources, Vol. 25, pp. 635-64.

Thomas, Duncan, Robert F. Schoeni, and John Strauss, 1996, "Parental Investments in Schooling: The Roles of Gender and Resources in Urban Brazil," Working Paper No. 96-02, RAND, Labor and Population Program.

United States Department of Labor, 1998, "By the Sweat \& Toil of Children," Volume V: Efforts to Eliminate Child Labor.

World Bank, 2001, "Brazil: Eradicating Child Labor in Brazil," Report No. 21858-BR.

Yang, Dean, 2007, "International Migration, Remittances, and Household Investment: Evidence from Philippine Migrants' Exchange Rate Shocks," Economic Journal, forthcoming. 
Table 1. The Work - School Enrollment Statistics of Children 10-14

Year

1989

1990

1992

1993

Change 93-89

All children 10-14

Not Working, Not in school

8.97

8.78

8.02

6.75

$-2.22$

Only Working

8.36

7.53

6.12

5.05

$-3.31$

9.76

9.83

12.78

13.18

3.42

Only School

72.9

73.86

$73.09 \quad 75.02$

2.11

Boys 10-14

Not Working, Not in school

7.24

6.72

7.18

6.15

$-1.09$

11.17

10.61

8.10

6.52

$-4.64$

Working and Going to School

13.53

13.45

17.14

17.67

4.14

68.06

69.22

67.59

69.65

1.59

Girls 10-14

Not Working, Not in school

10.67

10.86

8.88

7.35

$-3.32$

Only Working

5.58

4.42

4.08

3.55

$-2.03$

Working and Going to School

6.02

6.18

8.29

8.60

2.57

Only School

77.72

78.54

78.75

80.50

2.78

Notes: Source of data is the PNAD household survey. 
Table 2. Means: Boys

Total benefits (in hundreds of Reais of 1997)

Ratio of benefits to total income

Female benefits in household

Male benefits in household

\# Benefit receivers in household

\# Female beneficiaries in household

\# Male beneficiaries in household

Enrolled in school

Worked in reference week

Worked in reference week for pay

Total hours per week

Rural location

\# Elderly in household (males $>60$, females $>55$ )

\# Females 65 or older

\# Males 65 or older

Metropolitan region

Number of adults in household

Female-headed household

\# Children aged 0-4

\# Children aged 5-9

Only child in family

\# Children in family

Head: 1-4 years of schooling

Head: more than 4 years of schooling

Head's spouse: no schooling

Head's spouse: 1-4 years of schooling

Head's spouse: more than 4 years

Head of household age

Son or daughter of head

Related to the head

Number of observations
30180
0.163 [0.0084]

0.456 [0.016]

0.118 [0.0019]

0.045 [0.0012]

0.074 [0.0015]

0.87 [0.0018]

0.233 [0.0023]

0.087 [0.0015]

6.974 [0.0787]

$0.226[0.0023]$

0.132 [0.0022]

0.042 [0.0011]

0.03 [0.0009]

0.302 [0.0025]

2.3 [0.0051]

0.377 [0.0038]

0.726 [0.0047]

$0.061[0.0013]$

3.52 [0.0106]

0.41 [0.0027]

0.333 [0.0026]

0.185 [0.0021]

$0.359[0.0026]$

0.29 [0.0025]

43.487 [0.0511]

0.929 [0.0014]

0.069 [0.0014]

33406
0.151 [0.002]
0.199 [0.0069]

0.323 [0.016]

0.43 [0.0212]

0.649 [0.0166]

0.291 [0.012]

0.358 [0.0124]

0.657 [0.0121]

0.468 [0.0127]

0.15 [0.0091]

16.097 [0.4882]

$0.867[0.0087]$

$1.316[0.0123]$

0.323 [0.0122]

0.374 [0.0123]

0.049 [0.0055]

2.941 [0.0306]

0.4 [0.0189]

0.698 [0.0234]

0.077 [0.0068]

3.509 [0.0621]

0.298 [0.0116]

0.049 [0.0055]

0.51 [0.0127]

0.294 [0.0116]

0.043 [0.0051]

59.961 [0.2959]

0.733 [0.0113]

0.26 [0.0112]

1544
0.121 [0.0083]
$2.096[0.0653] \quad 1.253[0.0741]$

$0.369[0.0088] \quad 0.161[0.0112]$

$0.808[0.0383] \quad 0.438[0.0425]$

$1.288[0.0527] \quad 0.815[0.0605]$

$0.79[0.0171] \quad 0.148[0.0239]$

$0.322[0.012] \quad 0.032[0.0171]$

$0.468[0.0126] \quad 0.117[0.0178]$

$0.71[0.0111] \quad 0.013[0.0166]$

$0.496[0.0122] \quad 0.027[0.0179]$

$0.104[0.0075] \quad-0.013[0.012]$

$14.824[0.4354]-0.218[0.6632]$

$0.79[0.0099] \quad-0.012[0.0136]$

$1.349[0.0127] \quad 0.031[0.0179]$

$0.29[0.0114] \quad-0.036[0.0167]$

$0.39[0.0121] \quad 0.017[0.0174]$

$0.034[0.0044] \quad-0.016[0.0077]$

$2.937[0.0296] \quad 0.026[0.0431]$

$0.128[0.0082] \quad-0.008[0.0119]$

$0.388[0.0191] \quad 0.079[0.0274]$

$0.669[0.0221] \quad 0.094[0.0328]$

$0.083[0.0067] \quad-0.005[0.0097]$

$3.208[0.0568] \quad 0.054[0.0854]$

$0.288[0.0111] \quad 0.011[0.0164]$

$0.048[0.0052] \quad-0.05[0.0082]$

$0.5[0.0122] \quad 0.016[0.0179]$

$0.271[0.0109] \quad 0.006[0.0162]$

$0.059[0.0057] \quad-0.027[0.0083]$

$61.002[0.2882] \quad 1.201[0.4183]$

$0.666[0.0115] \quad-0.059[0.0162]$

$0.319[0.0114] \quad 0.052[0.016]$

1675

Notes: AFTER stands for observations for 1992 and 1993. BEFORE stands for 1989 and 1990 . TREAT stands for presence of at least one male with a rural occupation over 60 or a female over 55 with rural location. 


\begin{tabular}{|c|c|c|c|c|c|c|}
\hline & ALL & $\begin{array}{c}\text { BEFORE, } \\
\text { NOT TREAT }\end{array}$ & $\begin{array}{c}\text { AFTER, } \\
\text { NOT TREAT }\end{array}$ & BEFORE, TREAT & AFTER, TREAT & DIFF-DIFF \\
\hline Total benefits (in hundreds of Reais of 1997) & $0.632[0.0139]$ & $0.559[0.0214]$ & $0.619[0.0194]$ & $0.847[0.0517]$ & $1.95[0.0578]$ & $1.043[0.0816]$ \\
\hline Female benefits in household & $0.163[0.0056]$ & $0.123[0.0077]$ & $0.16[0.0086]$ & $0.328[0.0207]$ & $0.754[0.0302]$ & $0.389[0.0379]$ \\
\hline Male benefits in household & $0.469[0.0121]$ & $0.436[0.0194]$ & $0.459[0.0163]$ & $0.519[0.0426]$ & $1.196[0.0505]$ & $0.654[0.0699]$ \\
\hline \# Benefit receivers in household & $0.152[0.0016]$ & $0.128[0.0021]$ & $0.116[0.002]$ & $0.654[0.0169]$ & $0.751[0.0174]$ & $0.109[0.0244]$ \\
\hline \# Female beneficiaries in household & $0.058[0.0009]$ & $0.046[0.0012]$ & $0.043[0.0012]$ & $0.29[0.0123]$ & $0.316[0.0123]$ & $0.029[0.0174]$ \\
\hline \# Male beneficiaries in household & $0.094[0.0012]$ & $0.082[0.0016]$ & $0.073[0.0015]$ & $0.364[0.0127]$ & $0.435[0.0128]$ & 0.08 [0.0182] \\
\hline Enrolled in school & $0.867[0.0013]$ & $0.856[0.002]$ & $0.89[0.0017]$ & $0.699[0.012]$ & $0.787[0.0102]$ & $0.054[0.0159]$ \\
\hline Worked in reference week & $0.111[0.0012]$ & $0.099[0.0017]$ & $0.111[0.0017]$ & $0.19[0.0102]$ & $0.235[0.0106]$ & $0.033[0.0149]$ \\
\hline Worked in reference week for pay & $0.055[0.0009]$ & $0.062[0.0014]$ & $0.048[0.0012]$ & $0.085[0.0073]$ & $0.053[0.0056]$ & $-0.019[0.0093]$ \\
\hline Total hours per week & $3.567[0.0444]$ & $3.553[0.0669]$ & $3.274[0.0599]$ & $6.415[0.3788]$ & $6.386[0.3324]$ & $0.25[0.5103]$ \\
\hline Rural location & $0.274[0.0017]$ & $0.274[0.0026]$ & $0.216[0.0023]$ & $0.843[0.0095]$ & $0.791[0.0102]$ & $0.006[0.0142]$ \\
\hline \# Elderly in household (males $>60$, females $>55$ ) & $0.198[0.0019]$ & $0.137[0.0024]$ & $0.133[0.0023]$ & $1.33[0.0129]$ & $1.351[0.0129]$ & $0.025[0.0185]$ \\
\hline \# Females 65 or older & $0.056[0.0009]$ & $0.041[0.0012]$ & $0.041[0.0011]$ & $0.333[0.0126]$ & $0.311[0.0118]$ & $-0.021[0.0173]$ \\
\hline \# Males 65 or older & $0.048[0.0008]$ & $0.031[0.001]$ & $0.029[0.0009]$ & $0.364[0.0127]$ & $0.38[0.0125]$ & $0.019[0.0179]$ \\
\hline Metropolitan region & $0.291[0.0018]$ & $0.305[0.0027]$ & $0.306[0.0026]$ & $0.041[0.0052]$ & $0.039[0.0049]$ & $-0.003[0.0078]$ \\
\hline Number of adults in household & $2.352[0.0038]$ & $2.345[0.0055]$ & $2.29[0.0051]$ & $2.996[0.0323]$ & $2.973[0.0315]$ & $0.032[0.0456]$ \\
\hline Female-headed household & $0.148[0.0014]$ & $0.139[0.002]$ & $0.157[0.002]$ & $0.135[0.0089]$ & $0.138[0.0086]$ & $-0.015[0.0126]$ \\
\hline \# Children aged 0-4 & $0.429[0.0029]$ & $0.47[0.0044]$ & $0.39[0.0039]$ & $0.424[0.0202]$ & $0.4[0.0185]$ & $0.056[0.0279]$ \\
\hline \# Children aged 5-9 & $0.786[0.0035]$ & $0.853[0.0053]$ & $0.73[0.0048]$ & $0.725[0.0251]$ & $0.673[0.0223]$ & $0.071[0.0342]$ \\
\hline Only child in family & $0.055[0.0009]$ & $0.048[0.0012]$ & $0.06[0.0013]$ & $0.083[0.0072]$ & $0.075[0.0066]$ & $-0.019[0.0099]$ \\
\hline \# Children in family & $3.667[0.008]$ & $3.858[0.0122]$ & $3.514[0.0108]$ & $3.556[0.0669]$ & $3.206[0.0576]$ & $-0.006[0.0895]$ \\
\hline Head: $1-4$ years of schooling & $0.415[0.0019]$ & $0.434[0.0029]$ & $0.408[0.0027]$ & $0.312[0.0121]$ & $0.303[0.0115]$ & $0.017[0.017]$ \\
\hline Head: more than 4 years of schooling & $0.302[0.0018]$ & $0.289[0.0026]$ & $0.344[0.0026]$ & $0.045[0.0054]$ & $0.049[0.0054]$ & $-0.052[0.0083]$ \\
\hline Head's spouse: no schooling & $0.209[0.0016]$ & $0.206[0.0023]$ & $0.181[0.0021]$ & $0.502[0.013]$ & $0.482[0.0125]$ & $0.005[0.0183]$ \\
\hline Head's spouse: 1-4 years of schooling & $0.365[0.0019]$ & $0.385[0.0028]$ & $0.355[0.0027]$ & $0.284[0.0118]$ & $0.281[0.0112]$ & $0.026[0.0166]$ \\
\hline Head's spouse: more than 4 years & $0.264[0.0017]$ & $0.256[0.0025]$ & $0.295[0.0025]$ & $0.047[0.0055]$ & $0.056[0.0058]$ & $-0.03[0.0085]$ \\
\hline Head of household age & $44.351[0.0398]$ & $43.694[0.0536]$ & $43.276[0.052]$ & $59.737[0.3253]$ & $60.532[0.2976]$ & $1.213[0.4459]$ \\
\hline Son or daughter of head & $0.911[0.0011]$ & $0.923[0.0015]$ & $0.922[0.0015]$ & $0.725[0.0116]$ & $0.697[0.0115]$ & $-0.026[0.0165]$ \\
\hline Related to the head & $0.082[0.0011]$ & $0.071[0.0015]$ & $0.072[0.0014]$ & $0.26[0.0114]$ & $0.29[0.0113]$ & $0.029[0.0162]$ \\
\hline Number of observations & 65597 & 30161 & 32362 & 1472 & 1602 & \\
\hline
\end{tabular}

Notes: AFTER stands for observations for 1992 and 1993. BEFORE stands for 1989 and 1990. TREAT stands for presence of at least one male with a rural occupation over 60 or a female over 55 with rural location. 
Table 3. First Stage Regressions

\begin{tabular}{|c|c|c|c|}
\hline Dependent variable & $\begin{array}{c}1) \\
\text { TOTAL BENEFITS IN } \\
\text { HOUSEHOLD / } 100\end{array}$ & $\begin{array}{c}(2) \\
\text { MALE BENEFITS IN } \\
\text { HOUSEHOLD / } 100 \\
\end{array}$ & $\begin{array}{c}\text { (3) } \\
\text { FEMALE BENEFITS IN } \\
\text { HOUSEHOLD / } 100\end{array}$ \\
\hline \# Females, rural, aged 55-64 x AFTER & $\begin{array}{c}0.4079 \\
{[0.1622]^{*}}\end{array}$ & $\begin{array}{c}0.1878 \\
{[0.1207]}\end{array}$ & $\begin{array}{c}0.2201 \\
{[0.1020]^{*}}\end{array}$ \\
\hline \# Males, rural, aged 60-64 x AFTER & $\begin{array}{c}0.5403 \\
{[0.3616]}\end{array}$ & $\begin{array}{c}0.5969 \\
{[0.3378]}\end{array}$ & $\begin{array}{l}-0.0566 \\
{[0.0941]}\end{array}$ \\
\hline \# Females, rural, unmar., aged 65 up x AFTER & $\begin{array}{c}0.4636 \\
{[0.1997]^{*}}\end{array}$ & $\begin{array}{c}0.0559 \\
{[0.1354]}\end{array}$ & $\begin{array}{c}0.4077 \\
{[0.1397]^{* *}}\end{array}$ \\
\hline \# Males, rural, aged 65 up x AFTER & $\begin{array}{c}0.5215 \\
{[0.2593]^{*}}\end{array}$ & $\begin{array}{c}0.4052 \\
{[0.2415]}\end{array}$ & $\begin{array}{c}0.1163 \\
{[0.0795]}\end{array}$ \\
\hline \# Females, rural, aged 55-64 & $\begin{array}{l}-1.2449 \\
{[0.1921]^{* *}}\end{array}$ & $\begin{array}{l}-1.5549 \\
{[0.6979]^{*}}\end{array}$ & $\begin{array}{c}0.31 \\
{[0.7046]}\end{array}$ \\
\hline \# Males, rural, aged 60-64 & $\begin{array}{l}-2.2502 \\
{[0.2689]^{* *}}\end{array}$ & $\begin{array}{l}-2.249 \\
{[0.2603]^{* *}}\end{array}$ & $\begin{array}{l}-0.0012 \\
{[0.0577]}\end{array}$ \\
\hline \# Females, rural, unmarried, aged 65 up & $\begin{array}{l}-0.3896 \\
{[0.2118]}\end{array}$ & $\begin{array}{l}-0.815 \\
{[0.7019]}\end{array}$ & $\begin{array}{c}0.4254 \\
{[0.7059]}\end{array}$ \\
\hline \# Males, rural, aged 65 up & $\begin{array}{l}-1.606 \\
{[0.1864]^{* *}}\end{array}$ & $\begin{array}{l}-1.573 \\
{[0.1719]^{* *}}\end{array}$ & $\begin{array}{l}-0.033 \\
{[0.0602]}\end{array}$ \\
\hline \# Females 65 or older & $\begin{array}{c}0.4805 \\
{[0.2735]}\end{array}$ & $\begin{array}{c}0.0932 \\
{[0.2576]}\end{array}$ & $\begin{array}{c}0.3874 \\
{[0.0976]^{* *}}\end{array}$ \\
\hline \# Males 65 or older & $\begin{array}{c}2.2229 \\
{[0.3423]^{* *}}\end{array}$ & $\begin{array}{l}2.9143 \\
{[0.3134]^{* *}}\end{array}$ & $\begin{array}{l}-0.6913 \\
{[0.1311]^{* *}}\end{array}$ \\
\hline Number of adults in the household & $\begin{array}{c}1.0874 \\
{[0.2006]^{* *}}\end{array}$ & $\begin{array}{c}0.3979 \\
{[0.1914]^{*}}\end{array}$ & $\begin{array}{c}0.6894 \\
{[0.0678]^{* *}}\end{array}$ \\
\hline Female-headed household & $\begin{array}{l}-0.163 \\
{[0.0947]}\end{array}$ & $\begin{array}{l}-0.2711 \\
{[0.0709]^{* *}}\end{array}$ & $\begin{array}{c}0.1081 \\
{[0.0511]^{*}}\end{array}$ \\
\hline Household with head's spouse & $\begin{array}{l}-0.1236 \\
{[0.1072]}\end{array}$ & $\begin{array}{l}-0.1681 \\
{[0.0919]}\end{array}$ & $\begin{array}{c}0.0445 \\
{[0.0439]}\end{array}$ \\
\hline Head: $1-4$ years of schooling & $\begin{array}{c}0.1787 \\
{[0.0125]^{* *}}\end{array}$ & $\begin{array}{c}0.1468 \\
{[0.0107]^{* *}}\end{array}$ & $\begin{array}{c}0.0319 \\
{[0.0059]^{* *}}\end{array}$ \\
\hline Head: more than 4 years of schooling & $\begin{array}{c}0.7723 \\
{[0.0335]^{* *}}\end{array}$ & $\begin{array}{c}0.626 \\
{[0.0294]^{* *}}\end{array}$ & $\begin{array}{c}0.1463 \\
{[0.0157]^{* *}}\end{array}$ \\
\hline Head's spouse: no schooling & $\begin{array}{l}-0.1798 \\
{[0.0619]^{* *}}\end{array}$ & $\begin{array}{l}-0.1138 \\
{[0.0544]^{*}}\end{array}$ & $\begin{array}{l}-0.0661 \\
{[0.0222]^{* *}}\end{array}$ \\
\hline Head's spouse: 1-4 years of schooling & $\begin{array}{c}0.0717 \\
{[0.0612]}\end{array}$ & $\begin{array}{c}0.1085 \\
{[0.0537]^{*}}\end{array}$ & $\begin{array}{l}-0.0368 \\
{[0.0217]}\end{array}$ \\
\hline Head's spouse: more than 4 years & $\begin{array}{c}0.3784 \\
{[0.0647]^{* *}}\end{array}$ & $\begin{array}{c}0.2952 \\
{[0.0568]^{* *}}\end{array}$ & $\begin{array}{c}0.0832 \\
{[0.0235]^{* *}}\end{array}$ \\
\hline Observations & 132402 & 132402 & 132402 \\
\hline R-squared & 0.1174 & 0.105 & 0.0771 \\
\hline
\end{tabular}

Notes: The PNAD data sets for 1989, 1990, 1992 and 1993 were used for the regressions above. AFTER denotes the years of 1992 and 1993 . RURAL denotes rural household for females and rural occupation in the last 4 years for males. The sample consists of all children aged 10-14, with the exception of the ones from the Northern states. Regressors omitted from this table are racial dummies, number of adults in the household, dummies for second and third child in the household, and dummies for interactions between rural location and year; rural location and state of residence; state of residence and year; age of head of household and year; age of household head and rural location; age of the head spouse and year; age of head spouse and rural location. Single asterisk (*) stands for significant at 5 percent level; Double asterisk $(* *)$ stands for significant at 1 percent level. 
Table 4.Reduced Form Estimates

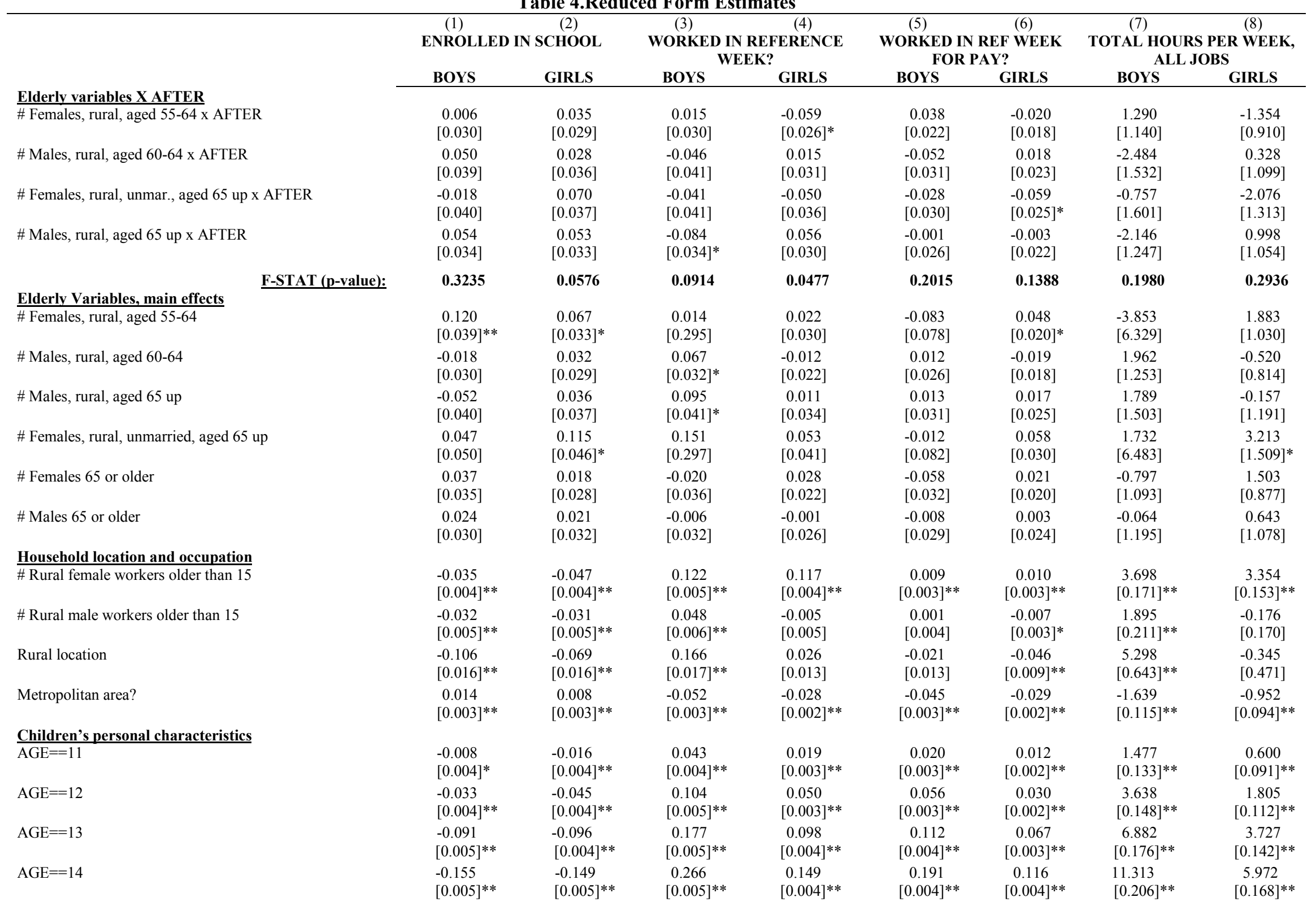




\begin{tabular}{|c|c|c|c|c|c|c|c|c|}
\hline \multirow[b]{3}{*}{ Sibling presence and family composition } & \multicolumn{2}{|c|}{ ENROLLED IN SCHOOL } & \multicolumn{2}{|c|}{ WORKED IN REF WEEK? } & \multicolumn{2}{|c|}{$\begin{array}{l}\text { WORKED IN REF } \\
\text { WEEK FOR PAY }\end{array}$} & \multicolumn{2}{|c|}{$\begin{array}{c}\text { TOTAL HOURS PER WEEK, } \\
\text { ALL JOBS }\end{array}$} \\
\hline & BOYS & GIRLS & BOYS & GIRLS & BOYS & GIRLS & BOYS & GIRLS \\
\hline & & & & & & & & \\
\hline Son or daughter of the head & $\begin{array}{l}0.169 \\
{[0.034]^{* *}}\end{array}$ & $\begin{array}{l}0.152 \\
{[0.024]^{* *}}\end{array}$ & $\begin{array}{l}-0.202 \\
{[0.032]^{* *}}\end{array}$ & $\begin{array}{c}0.019 \\
{[0.013]}\end{array}$ & $\begin{array}{l}-0.091 \\
{[0.029]^{* *}}\end{array}$ & $\begin{array}{c}0.017 \\
{[0.010]}\end{array}$ & $\begin{array}{l}-8.766 \\
{[1.228]^{* *}}\end{array}$ & $\begin{array}{c}0.247 \\
{[0.505]}\end{array}$ \\
\hline Other relative to the head & $\begin{array}{l}0.146 \\
{[0.034]^{* *}}\end{array}$ & $\begin{array}{l}0.124 \\
{[0.023]^{* *}}\end{array}$ & $\begin{array}{l}-0.178 \\
{[0.032]^{* *}}\end{array}$ & $\begin{array}{l}0.033 \\
{[0.013]^{* *}}\end{array}$ & $\begin{array}{l}-0.067 \\
{[0.029]^{*}}\end{array}$ & $\begin{array}{c}0.028 \\
{[0.009]^{* *}}\end{array}$ & $\begin{array}{l}-7.543 \\
{[1.217]^{* *}}\end{array}$ & $\begin{array}{c}0.946 \\
{[0.477]^{*}}\end{array}$ \\
\hline \# Children 0-4 in household & $\begin{array}{l}-0.043 \\
{[0.003]^{* *}}\end{array}$ & $\begin{array}{l}-0.047 \\
{[0.003]^{* *}}\end{array}$ & $\begin{array}{l}0.019 \\
{[0.003]^{* *}}\end{array}$ & $\begin{array}{c}0.003 \\
{[0.002]}\end{array}$ & $\begin{array}{c}0.015 \\
{[0.002]^{* *}}\end{array}$ & $\begin{array}{c}0.002 \\
{[0.002]}\end{array}$ & $\begin{array}{l}0.790 \\
{[0.106]^{* *}}\end{array}$ & $\begin{array}{l}0.266 \\
{[0.092]^{* *}}\end{array}$ \\
\hline \# Children 5-9 in household & $\begin{array}{l}-0.012 \\
{[0.003]^{* *}}\end{array}$ & $\begin{array}{l}-0.013 \\
{[0.002]^{* *}}\end{array}$ & $\begin{array}{l}0.014 \\
{[0.003]^{* *}}\end{array}$ & $\begin{array}{c}0.003 \\
{[0.002]}\end{array}$ & $\begin{array}{c}0.003 \\
{[0.002]}\end{array}$ & $\begin{array}{c}0.000 \\
{[0.002]}\end{array}$ & $\begin{array}{l}0.403 \\
{[0.103]^{* *}}\end{array}$ & $\begin{array}{c}0.095 \\
{[0.085]}\end{array}$ \\
\hline Oldest child in family & $\begin{array}{l}-0.010 \\
{[0.008]}\end{array}$ & $\begin{array}{l}0.027 \\
{[0.008]^{* *}}\end{array}$ & $\begin{array}{l}0.052 \\
{[0.009]^{* *}}\end{array}$ & $\begin{array}{l}0.029 \\
{[0.007]^{* *}}\end{array}$ & $\begin{array}{l}0.018 \\
{[0.007]^{*}}\end{array}$ & $\begin{array}{c}0.010 \\
{[0.005]}\end{array}$ & $\begin{array}{c}1.936 \\
{[0.327]^{* *}}\end{array}$ & $\begin{array}{l}1.069 \\
{[0.260]^{* *}}\end{array}$ \\
\hline Youngest child in family & -0.004 & 0.003 & -0.011 & -0.003 & -0.010 & -0.009 & -0.294 & -0.096 \\
\hline Only child in family & $\begin{array}{l}{[0.004]} \\
-0.025 \\
{[0.007]^{* *}}\end{array}$ & $\begin{array}{l}{[0.004]} \\
-0.016 \\
{[0.007]^{*}}\end{array}$ & $\begin{array}{c}{[0.005]^{*}} \\
0.009 \\
{[0.008]}\end{array}$ & $\begin{array}{c}{[0.004]} \\
0.005 \\
{[0.006]}\end{array}$ & $\begin{array}{c}{[0.004]^{*}} \\
0.004 \\
{[0.006]}\end{array}$ & $\begin{array}{c}{[0.003]^{* *}} \\
0.009 \\
{[0.005]}\end{array}$ & $\begin{array}{c}{[0.179]} \\
0.362 \\
{[0.294]}\end{array}$ & $\begin{array}{c}{[0.149]} \\
0.262 \\
{[0.223]}\end{array}$ \\
\hline \# Children in family & $\begin{array}{l}-0.001 \\
{[0.002]}\end{array}$ & $\begin{array}{c}0.005 \\
{[0.002]^{* *}}\end{array}$ & $\begin{array}{c}0.004 \\
{[0.002]^{*}}\end{array}$ & $\begin{array}{c}0.009 \\
{[0.001]^{* *}}\end{array}$ & $\begin{array}{c}0.002 \\
{[0.001]}\end{array}$ & $\begin{array}{c}0.006 \\
{[0.001]^{* *}}\end{array}$ & $\begin{array}{c}0.158 \\
{[0.067]^{*}}\end{array}$ & $\begin{array}{c}0.348 \\
{[0.056]^{* *}}\end{array}$ \\
\hline \multicolumn{9}{|l|}{ Adults and household structure } \\
\hline Female-headed household & $\begin{array}{c}0.026 \\
{[0.012]^{*}}\end{array}$ & $\begin{array}{c}0.029 \\
{[0.011]^{* *}}\end{array}$ & $\begin{array}{l}-0.025 \\
{[0.011]^{*}}\end{array}$ & $\begin{array}{c}0.001 \\
{[0.009]}\end{array}$ & $\begin{array}{c}0.012 \\
{[0.010]}\end{array}$ & $\begin{array}{c}0.010 \\
{[0.008]}\end{array}$ & $\begin{array}{l}-0.863 \\
{[0.454]}\end{array}$ & $\begin{array}{l}-0.248 \\
{[0.358]}\end{array}$ \\
\hline Household with head's spouse & $\begin{array}{l}0.138 \\
{[0.031]^{* *}}\end{array}$ & $\begin{array}{l}0.114 \\
{[0.026]^{* *}}\end{array}$ & $\begin{array}{l}-0.024 \\
{[0.045]}\end{array}$ & $\begin{array}{l}-0.029 \\
{[0.031]}\end{array}$ & $\begin{array}{l}-0.050 \\
{[0.031]}\end{array}$ & $\begin{array}{c}0.016 \\
{[0.031]}\end{array}$ & $\begin{array}{l}-1.089 \\
{[1.613]}\end{array}$ & $\begin{array}{l}-1.206 \\
{[1.022]}\end{array}$ \\
\hline Head: $1-4$ years of schooling & $\begin{array}{l}0.078 \\
{[0.005]^{* *}}\end{array}$ & $\begin{array}{c}0.053 \\
{[0.004]^{* *}}\end{array}$ & $\begin{array}{l}-0.030 \\
{[0.005]^{* *}}\end{array}$ & $\begin{array}{l}-0.017 \\
{[0.004]^{* *}}\end{array}$ & $\begin{array}{c}-0.028 \\
{[0.004]^{* *}}\end{array}$ & $\begin{array}{c}-0.016 \\
{[0.003]^{* *}}\end{array}$ & $\begin{array}{l}-1.480 \\
{[0.176]^{* *}}\end{array}$ & $\begin{array}{l}-0.747 \\
{[0.147]^{* *}}\end{array}$ \\
\hline Head: more than 4 years of schooling & $\begin{array}{c}0.123 \\
{[0.005]^{* *}}\end{array}$ & $\begin{array}{c}0.083 \\
{[0.005]^{* *}}\end{array}$ & $\begin{array}{l}-0.079 \\
{[0.005]^{* *}}\end{array}$ & $\begin{array}{l}-0.043 \\
{[0.004]^{* *}}\end{array}$ & $\begin{array}{l}-0.066 \\
{[0.004]^{* *}}\end{array}$ & $\begin{array}{c}-0.044 \\
{[0.003]^{* *}}\end{array}$ & $\begin{array}{l}-3.199 \\
{[0.193]^{* *}}\end{array}$ & $\begin{array}{l}-1.900 \\
{[0.153]^{* *}}\end{array}$ \\
\hline Head's spouse: no schooling & $\begin{array}{l}-0.143 \\
{[0.030]^{* *}}\end{array}$ & $\begin{array}{l}-0.113 \\
{[0.024]^{* *}}\end{array}$ & $\begin{array}{c}0.024 \\
{[0.044]}\end{array}$ & $\begin{array}{c}0.029 \\
{[0.030]}\end{array}$ & $\begin{array}{c}0.059 \\
{[0.030]^{*}}\end{array}$ & $\begin{array}{l}-0.005 \\
{[0.031]}\end{array}$ & $\begin{array}{l}1.106 \\
{[1.571]}\end{array}$ & $\begin{array}{c}1.200 \\
{[0.981]}\end{array}$ \\
\hline Head's spouse: 1-4 years of schooling & $\begin{array}{l}-0.055 \\
{[0.029]}\end{array}$ & $\begin{array}{l}-0.054 \\
{[0.024]^{*}}\end{array}$ & $\begin{array}{c}0.017 \\
{[0.044]}\end{array}$ & $\begin{array}{c}0.022 \\
{[0.030]}\end{array}$ & $\begin{array}{c}0.033 \\
{[0.030]}\end{array}$ & $\begin{array}{l}-0.018 \\
{[0.031]}\end{array}$ & $\begin{array}{c}0.413 \\
{[1.563]}\end{array}$ & $\begin{array}{c}0.588 \\
{[0.971]}\end{array}$ \\
\hline Head's spouse: more than 4 years & $\begin{array}{l}-0.045 \\
{[0.029]}\end{array}$ & $\begin{array}{l}-0.031 \\
{[0.024]}\end{array}$ & $\begin{array}{l}-0.016 \\
{[0.044]}\end{array}$ & $\begin{array}{c}0.011 \\
{[0.030]}\end{array}$ & $\begin{array}{c}0.011 \\
{[0.030]}\end{array}$ & $\begin{array}{l}-0.03 \\
{[0.031]}\end{array}$ & $\begin{array}{l}-0.84 \\
{[1.561]}\end{array}$ & $\begin{array}{c}0.137 \\
{[0.969]}\end{array}$ \\
\hline Observations & 66805 & 65597 & 66805 & 65597 & 66805 & 65597 & 66796 & 65591 \\
\hline R-squared & 0.1590 & 0.1397 & 0.2637 & 0.1448 & 0.0886 & 0.0613 & 0.2445 & 0.1207 \\
\hline
\end{tabular}

Notes:

The PNAD data sets for 1989, 1990, 1992 and 1993 were used for the regressions above. Sample consists of all children aged 10-14 not from the Northern region (where rural households were not covered by the survey).

AFTER denotes the years of 1992 and 1993. RURAL denotes rural household for females and rural occupation in the last 4 years for males. Regressors omitted from this table are racial dummies, number of adults in the household, dummies for second and third child in the household, and dummies for interactions between rural location and year; rural location and state of residence; state of residence and year; age of head of household and year; age of household head and rural location; age of the head spouse and year; age of head spouse and rural location.

Single asterisk $(*)$ stands for significant at 5 percent level; Double asterisk $(* *)$ stands for significant at 1 percent level. Both are two-tailed tests. 
Table 5.

Panel 1. Actual and Counterfactual Values for Treated Group, after the Reform

\begin{tabular}{|c|c|c|c|c|c|c|}
\hline & \multicolumn{3}{|c|}{ BOYS } & \multicolumn{3}{|c|}{ GIRLS } \\
\hline & ACTUAL & $\begin{array}{l}\text { COUNTER- } \\
\text { FACTUAL }\end{array}$ & $\begin{array}{c}\text { EFFECT OF } \\
\text { REFORM }\end{array}$ & ACTUAL & $\begin{array}{l}\text { COUNTER- } \\
\text { FACTUAL }\end{array}$ & $\begin{array}{c}\text { EFFECT OF } \\
\text { REFORM }\end{array}$ \\
\hline ENROLLED IN SCHOOL & $\begin{array}{c}0.709 \\
{[0.0110]}\end{array}$ & $\begin{array}{c}0.676 \\
{[0.0155]}\end{array}$ & $\begin{array}{c}0.0324 \\
{[0.0179]}\end{array}$ & $\begin{array}{c}0.790 \\
{[0.0093]}\end{array}$ & $\begin{array}{c}0.739 \\
{[0.0163]}\end{array}$ & $\begin{array}{c}0.0506 \\
{[0.0188]}\end{array}$ \\
\hline WORKED IN REFERENCE WEEK & $\begin{array}{c}0.504 \\
{[0.0126]}\end{array}$ & $\begin{array}{c}0.547 \\
{[0.0161]}\end{array}$ & $\begin{array}{l}-0.0436 \\
{[0.0188]}\end{array}$ & $\begin{array}{c}0.240 \\
{[0.0105]}\end{array}$ & $\begin{array}{c}0.249 \\
{[0.0133]}\end{array}$ & $\begin{array}{l}-0.0089 \\
{[0.0141]}\end{array}$ \\
\hline WORKED IN REF WEEK FOR PAY & $\begin{array}{c}0.100 \\
{[0.0080]}\end{array}$ & $\begin{array}{c}0.107 \\
{[0.0125]}\end{array}$ & $\begin{array}{l}-0.0074 \\
{[0.0144]}\end{array}$ & $\begin{array}{c}0.055 \\
{[0.0062]}\end{array}$ & $\begin{array}{c}0.070 \\
{[0.0101]}\end{array}$ & $\begin{array}{l}-0.0148 \\
{[0.0113]}\end{array}$ \\
\hline TOTAL HOURS PER WEEK, ALL JOBS & $\begin{array}{l}15.06 \\
{[0.407]}\end{array}$ & $\begin{array}{l}16.23 \\
{[0.633]}\end{array}$ & $\begin{array}{l}-1.168 \\
{[0.712]}\end{array}$ & $\begin{array}{c}6.64 \\
{[0.337]}\end{array}$ & $\begin{array}{c}7.08 \\
{[0.539]}\end{array}$ & $\begin{array}{l}-0.435 \\
{[0.568]}\end{array}$ \\
\hline
\end{tabular}

Panel 2. Actual and Counterfactual Estimates of Aggregate Effects of the Reform

Number of families affected by the reform Additional benefit income, total

Increase in enrollment, total

Increase in enrollment
In Millions of households In Millions of Reais of 1997, per

month

In Thousands of children

In percent of 10-14 population
Male benefits

0.37

12.35

Boys

28.80

0.29

\section{Female benefits}

0.45

27.79

Girls

44.41

0.45
Total benefits

0.69

40.14

All

73.22

0.37

Notes: The treated group consists of all children aged 10-14 with at least one elderly affected by the reform in their household (for which not all excluded variables are equal to zero). Reduced form regression estimates, as reported in Table 5, are used to construct the actual and counterfactual values of the outcome variables. The actual values are the average predicted values from the reduced form regressions. The counterfactual is constructed by subtracting the effect of the excluded variables from the fitted values of the same regression. The "effect of the reform" is the difference in the average for the actual and counterfactual outcomes. Bootstrapped standard errors are in brackets. 
Table 6. Estimates Of The Effect Of Monthly Benefits Coefficient is The Estimated Effect of $\$ 100$ in Social Security Income

\begin{tabular}{|c|c|c|c|c|c|c|}
\hline & $\begin{array}{c}(1) \\
\text { OLS }\end{array}$ & $\begin{array}{l}\text { (2) } \\
\text { IV }\end{array}$ & $\begin{array}{l}\text { (3) } \\
\text { IV }\end{array}$ & $\begin{array}{c}(4) \\
\text { OLS }\end{array}$ & $\begin{array}{l}\text { (5) } \\
\text { IV }\end{array}$ & $\begin{array}{l}\text { (6) } \\
\text { IV }\end{array}$ \\
\hline & \multicolumn{6}{|c|}{ ENROLLED IN SCHOOL } \\
\hline & \multicolumn{3}{|c|}{ BOYS } & \multicolumn{3}{|c|}{ GIRLS } \\
\hline Total benefits in household & $\begin{array}{l}0.0008 \\
{[0.0002]^{* * *}}\end{array}$ & $\begin{array}{l}0.029 \\
\quad[0.0450]\end{array}$ & & $\begin{array}{l}0.0002 \\
\quad[0.0003]\end{array}$ & $\begin{array}{l}0.0625 \\
{[0.0302]^{* *}}\end{array}$ & \\
\hline Female benefits in household & & & $\begin{array}{l}-0.0914 \\
{[0.1549]}\end{array}$ & & & $\begin{array}{c}0.1263 \\
{[0.0774]}\end{array}$ \\
\hline Male benefits in household & & & $\begin{array}{c}0.1379 \\
{[0.1618]}\end{array}$ & & & $\begin{array}{c}0.0389 \\
{[0.0383]}\end{array}$ \\
\hline \multirow[t]{3}{*}{ F-test: female $=$ male benefits $(\mathrm{P}$-value $)$} & & & 0.4273 & & & 0.355 \\
\hline & \multicolumn{6}{|c|}{ WORKED IN REFERENCE WEEK? } \\
\hline & \multicolumn{3}{|c|}{ BOYS } & \multicolumn{3}{|c|}{ GIRLS } \\
\hline Total benefits in household & $\begin{array}{l}-0.0015 \\
{[0.0003]^{* * *}}\end{array}$ & $\begin{array}{l}-0.0629 \\
{[0.0505]}\end{array}$ & & $\begin{array}{l}-0.0011 \\
{[0.0002]^{* * *}}\end{array}$ & $\begin{array}{c}0.0019 \\
{[0.0217]}\end{array}$ & \\
\hline Female benefits in household & & & $\begin{array}{l}-0.0525 \\
{[0.1217]}\end{array}$ & & & $\begin{array}{l}-0.1169 \\
{[0.0724]}\end{array}$ \\
\hline Male benefits in household & & & $\begin{array}{l}-0.0723 \\
{[0.1185]}\end{array}$ & & & $\begin{array}{c}0.0459 \\
{[0.0357]}\end{array}$ \\
\hline \multirow[t]{3}{*}{ F-test: female $=$ male benefits $(\mathrm{P}$-value $)$} & & & 0.9275 & & & 0.0634 \\
\hline & \multicolumn{6}{|c|}{ WORKED IN REFERENCE WEEK FOR PAY } \\
\hline & \multicolumn{3}{|c|}{ BOYS } & \multicolumn{3}{|c|}{ GIRLS } \\
\hline Total benefits in household & $\begin{array}{l}-0.0011 \\
{[0.0003]^{* * *}}\end{array}$ & $\begin{array}{l}-0.0208 \\
{[0.0335]}\end{array}$ & & $\begin{array}{l}-0.0007 \\
{[0.0001] * * *}\end{array}$ & $\begin{array}{l}-0.0133 \\
{[0.0160]}\end{array}$ & \\
\hline Female benefits in household & & & $\begin{array}{c}0.0051 \\
{[0.0851]}\end{array}$ & & & $\begin{array}{l}-0.1022 \\
{[0.0547]^{*}}\end{array}$ \\
\hline Male benefits in household & & & $\begin{array}{l}-0.0441 \\
{[0.0827]}\end{array}$ & & & $\begin{array}{c}0.0197 \\
{[0.0248]}\end{array}$ \\
\hline \multirow[t]{3}{*}{ F-test: female $=$ male benefits $(\mathrm{P}$-value $)$} & & & 0.7466 & & & 0.0594 \\
\hline & \multicolumn{6}{|c|}{ TOTAL HOURS PER WEEK, ALL JOBS } \\
\hline & & BOYS & & & GIRLS & \\
\hline Total benefits in household & $\begin{array}{l}-0.0526 \\
{[0.0101]^{* * *}}\end{array}$ & $\begin{array}{l}-1.3758 \\
{[1.7727]}\end{array}$ & & $\begin{array}{l}-0.0353 \\
{[0.0066]^{* * *}}\end{array}$ & $\begin{array}{l}-0.2387 \\
{[0.7629]}\end{array}$ & \\
\hline Female benefits in household & & & $\begin{array}{c}1.0605 \\
{[4.9559]}\end{array}$ & & & $\begin{array}{l}-3.8236 \\
{[2.5106]}\end{array}$ \\
\hline Male benefits in household & & & $\begin{array}{l}-3.5878 \\
{[5.0102]}\end{array}$ & & & $\begin{array}{c}1.088 \\
{[1.1603]}\end{array}$ \\
\hline F-test: female = male benefits $(\mathrm{P}$-value $)$ & & & 0.609 & & & 0.1037 \\
\hline
\end{tabular}

Notes:

The PNAD data sets for 1989, 1990, 1992 and 1993 were used for the regressions above. Sample consists of all children aged 10-14 not from the Northern region (where rural households were not covered by the survey).

Instruments for the benefit amount variables are \# Females, rural, aged 55-64 x AFTER; \# Males, rural, aged 60-64 x AFTER; \# Females, rural, unmarried, aged 65 up x AFTER; and \# Males, rural, aged 65 up x AFTER.

Additional controls are the same as in Table 4. $(*),(* *)$ and $(* * *)$ denote significance at the 10,5 and 1 percent level respectively. 
Table 7.Instrumental Variables Estimates Of The Effect Of Benefits For Different Subsamples

\begin{tabular}{|c|c|c|c|c|c|c|c|c|}
\hline & DEPEN & NT VARIA] & E: ENROLL & IN SCHOO & & & & \\
\hline & BOYS & & & & GIRLS & & & \\
\hline & & (1) & (2a) & (2b) & & (3) & (4a) & (4b) \\
\hline Prop. full & Mean dep. & TOTAL & MALE & FEMALE & Mean dep & TOTAL & MALE & FEMALE \\
\hline sample & Variable & BENEFITS & BENEFITS & BENEFITS & variable & BENEFITS & BENEFITS & BENEFITS \\
\hline 1.000 & 0.690 & 0.029 & 0.138 & -0.091 & 0.746 & 0.063 & 0.039 & 0.126 \\
\hline & & {$[0.0450]$} & {$[0.1618]$} & [0.1549] & & {$[0.0302]^{* *}$} & {$[0.0383]$} & {$[0.0774]$} \\
\hline 0.410 & 0.794 & -0.0124 & 0.017 & -0.0557 & 0.838 & 0.002 & 0.0193 & -0.0754 \\
\hline & & {$[0.0546]$} & {$[0.0897]$} & {$[0.1114]$} & & {$[0.0191]$} & {$[0.0292]$} & {$[0.0981]$} \\
\hline 0.590 & 0.630 & 0.0405 & 0.0709 & -0.076 & 0.689 & 0.0399 & -0.006 & 0.198 \\
\hline & & [0.0497] & {$[0.0659]$} & {$[0.1389]$} & & {$[0.0335]$} & {$[0.0430]$} & {$[0.1203]$} \\
\hline 0.306 & 0.689 & 0.097 & 0.136 & 0.027 & 0.746 & 0.058 & 0.037 & 0.156 \\
\hline & & [0.0799] & {$[0.1236]$} & {$[0.1351]$} & & {$[0.0317]^{*}$} & {$[0.0373]$} & {$[0.1052]$} \\
\hline 0.281 & 0.678 & -0.058 & -0.350 & 0.085 & 0.725 & 0.022 & 0.012 & 0.172 \\
\hline & & [0.1407] & {$[0.3893]$} & {$[0.2609]$} & & {$[0.0252]$} & {$[0.0341]$} & {$[0.3642]$} \\
\hline N/A & 0.736 & 0.042 & 0.069 & -0.031 & 0.781 & 0.036 & 0.011 & 0.113 \\
\hline & & {$[0.0201]^{* *}$} & {$[0.0358]^{*}$} & {$[0.0768]$} & & {$[0.0162]^{* *}$} & {$[0.0270]$} & {$[0.0743]$} \\
\hline 0.350 & 0.672 & 0.022 & 0.125 & -0.093 & 0.765 & 0.158 & 0.122 & 0.268 \\
\hline & & [0.0444] & {$[0.1352]$} & {$[0.1292]$} & & {$[0.1061]$} & {$[0.1360]$} & {$[0.2970]$} \\
\hline 0.699 & 0.679 & 0.049 & 0.276 & -0.468 & 0.739 & 0.069 & 0.033 & 0.090 \\
\hline & & {$[0.0356]$} & {$[0.3255]$} & {$[0.7414]$} & & {$[0.0367]^{*}$} & {$[0.0707]$} & {$[0.0505]^{*}$} \\
\hline 0.311 & 0.674 & 0.042 & 0.072 & -0.152 & 0.747 & 0.016 & 0.071 & -0.079 \\
\hline & & {$[0.0458]$} & {$[0.0630]$} & {$[0.2350]$} & & {$[0.0446]$} & {$[0.0752]$} & [0.1048] \\
\hline 0.532 & 0.694 & 0.039 & 0.206 & -0.033 & 0.754 & 0.059 & 0.031 & 0.193 \\
\hline & & {$[0.0568]$} & [0.2097] & {$[0.0987]$} & & {$[0.0356]^{*}$} & {$[0.0439]$} & {$[0.1518]$} \\
\hline DF & NDENT VA & IABLE: WO & KED IN REF & RENCE WE & & & & \\
\hline 1.000 & 0.690 & -0.0629 & -0.0723 & -0.0525 & 0.746 & 0.0019 & 0.0459 & -0.1169 \\
\hline & & {$[0.0505]$} & {$[0.1185]$} & {$[0.1217]$} & & {$[0.0217]$} & {$[0.0357]$} & {$[0.0724]$} \\
\hline 0.410 & 0.794 & -0.033 & -0.029 & -0.040 & 0.838 & -0.018 & 0.007 & -0.127 \\
\hline & & {$[0.0661]$} & {$[0.0990]$} & {$[0.1314]$} & & {$[0.0183]$} & {$[0.0248]$} & {$[0.0971]$} \\
\hline 0.590 & 0.630 & -0.036 & -0.034 & -0.044 & 0.689 & 0.040 & 0.073 & -0.074 \\
\hline & & [0.0489] & {$[0.0571]$} & [0.1184] & & {$[0.0334]$} & [0.0483] & [0.0916] \\
\hline
\end{tabular}

\section{SAMPLE}

1) Full Sample

2) Children 10-11

3) Children 12-14

4) Household with 50 or older person

5) Household in a rural location

6) Pre reform: 89-90, After: 95-97

7) Household in Northeastern

8) Head has $<4$ years of schooling

9) Presence of children younger than 5

10) Presence of children aged 5 to 9

1) Full Sample

2) Children 10-11

3) Children 12-14
[0.0334]

Notes: This table reports the coefficients on total benefits, male benefits and female benefits in regression similar to the ones reported in Table 6 . An adult is defined as a person older than 20. $(*),(* *)$ and $(* * *)$ denote significance at the 10,5 and 1 percent level respectively. 
Table 8. Reduced Form Estimates

Has The Reform Changed The Percentage Of Elderly Coresiding With Children 10 To 14 ?

Variable

\# BOYS 10-14 IN HOUSEHOLD

Sample

ELDERLY MEN

ELDERLY WOMEN

ELDERLY MEN ELDERLY WOMEN

Became eligible due to reform, AFTER

$\begin{array}{cl}0.0413 & -0.0066 \\ {[0.0238]} & {[0.0208]} \\ 0.0204 & -0.0091 \\ {[0.0196]} & {[0.0252]}\end{array}$

$-0.0044$

0.0308

[0.0219]

[0.0232]

Benefits doubled due to reform, AFTER

[0.0196]

$-0.0248$

0.0245

[0.0260]

[0.0189]

F-STAT (p-value):

0.2167

0.4987

0.3137

0.9331

Observations

75601

87635

75601

87635

R-squared

0.0556

0.0371

0.0517

0.0322

Notes: The PNAD data sets for 1989, 1990, 1992 and 1993 were used for the regressions above. AFTER denotes the years of 1992 and 1993. "Became eligible due to reform" denotes males 60 to 64 with rural occupations (in the last 4 years) or females 55 to 64 living in a rural location, or females 65 or older, married and living in a rural location. "Benefits doubled due to reform" denotes males 65 or older with rural occupations (in the last 4 years), or females 65 or older, unmarried, living in a rural location. Sample consists of all people 50 or older, living in regions other than the Northern states, where rural households were not surveyed.

Regressors omitted from this table are dummies for interactions between rural location and year, rural location and age, age and year, and rural location and state of residence, plus dummies for married status and metropolitan area. Single asterisk $(*)$ stands for significant at 5 percent level; Double asterisk (**) stands for significant at 1 percent level.F-Stat is the test for joint significance for the coefficients reported in this table. 


\section{Figure 1}

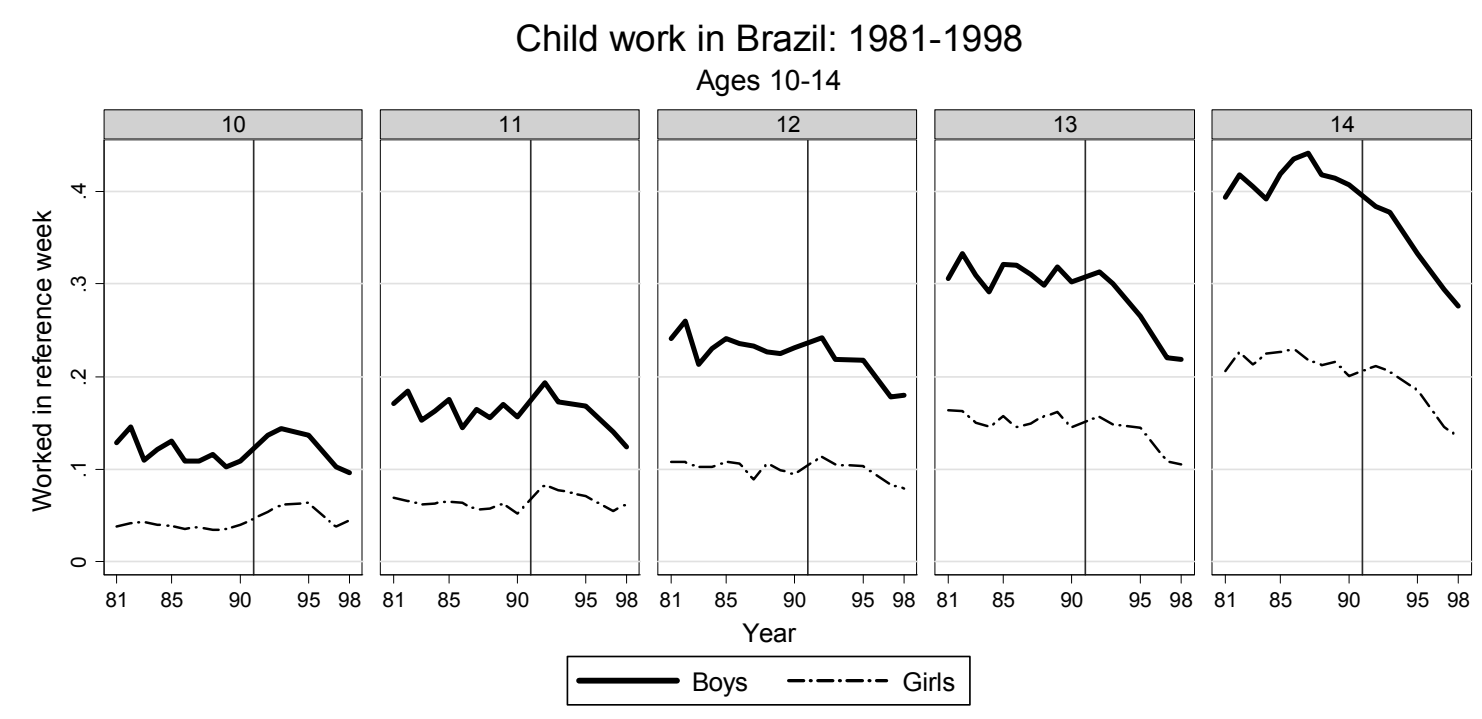

The figures above show the time series behavior of the proportion of boys and girls who "worked in the reference week" from the PNAD household survey. The vertical line on 91 divides the period in before and after the reform.

\section{Figure 2}

School enrollment in Brazil: 1981-1998
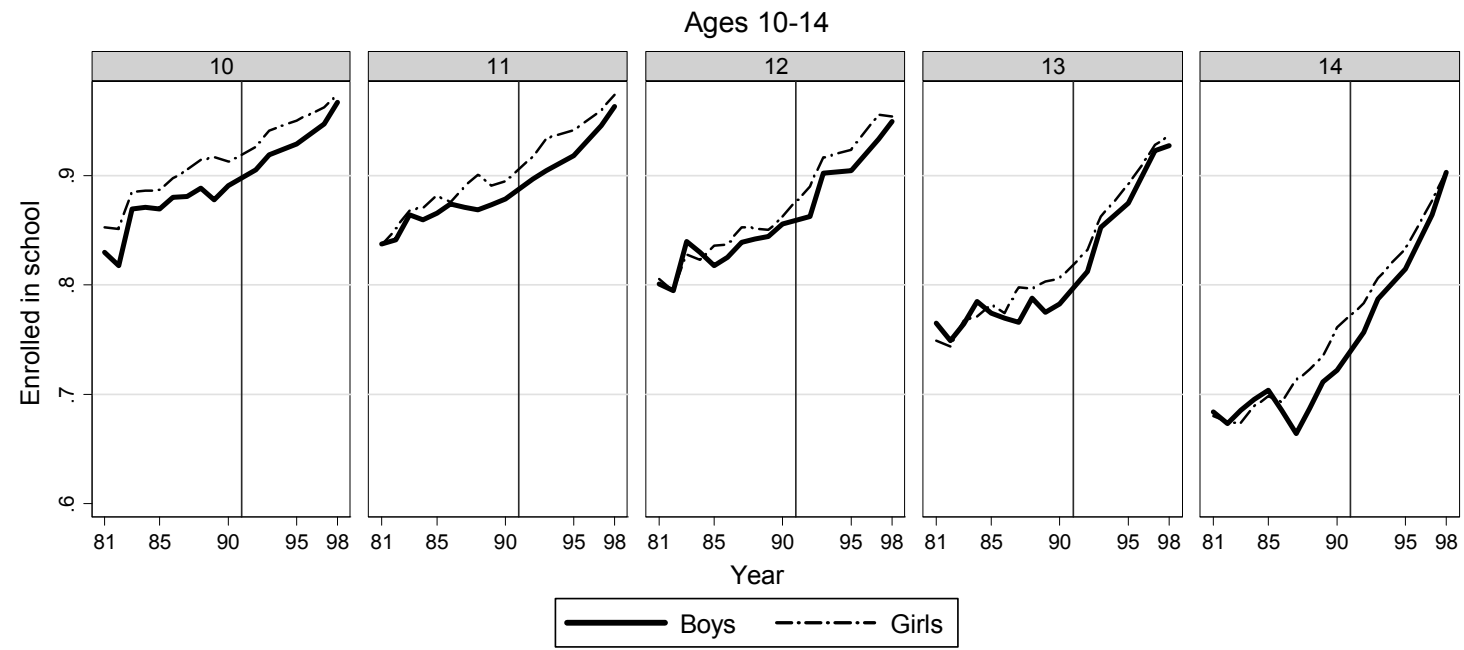

Boys -.-.-.- Girls

The figures above show the time series behavior of the proportion of boys and girls who are "enrolled in school" from the PNAD household survey. The vertical line on 91 divides the period in before and after the reform. 
${ }^{1}$ Edmonds (2007) is an useful review of the literature.

${ }^{2}$ But Kruger (2007) finds that positive shocks to coffee production increase child labor in Brazilian coffee production counties

${ }^{3}$ Before the reform, old-age benefits for rural workers were flat and equal to 50 percent of the minimum wage. After the reform, rural workers could opt for benefits based on past earnings, but the vast majority of rural old-age beneficiaries had benefits equal to the minimum benefit, fixed by the reform at one minimum wage. For a longer and more detailed account of the reform, see de Carvalho Filho (2000A).

4 This research strategy is akin to the papers by Duflo (1999) and Bertrand, Miller and Mullainathan (2003) that explored the effects of social pensions in South Africa on respectively children health outcomes and labor force participation of prime-aged males coresiding with pensioners.

${ }^{5}$ Source: ILO (1996), based on statistics organized by Ashagrie (1993), as quoted in Basu (1999).

${ }^{6}$ From now on, when I refer to children, I mean age 10-14.

7 Krueger (1996) argues that compulsory schooling laws are usually not enforced in developing countries.

${ }^{8}$ For an evaluation of the PETI program, see World Bank

${ }^{9}$ After 1990 there were changes in the survey instrument affecting the labor participation questions. That will bias the estimates for this paper if those changes affect observed responses in a manner that is correlated with the presence of rural workers affected by the reform in one's household.

${ }^{10}$ The estimates in this paper are not significantly affected by this change.

11. It is crucial that there be no changes in living arrangements for this empirical strategy to provide consistent estimates. In Section VI I argue that endogeneity of living arrangements and selection problems does not seem to be a major problem.

${ }^{12}$ It is implicitly assumed that the effect of living with an elderly is time-invariant during the period covered by this paper.

13. The results in this paper are robust to exclusion of variables capturing the presence of siblings' availability and their characteristics. 
${ }^{14}$ As already shown in de Carvalho Filho (2000A).

15 Throughout this paper, monetary values are measured in Reais of 1997, when R\$1 was approximately equal to US\$1. In 1990, the median monthly wage for male rural workers age 20-50 was $\mathrm{R} \$ 141.54$ in the Northeastern region, the poorest one, and $\mathrm{R} \$ 223$ for the rest of the country.

${ }^{16}$ de Carvalho Filho (2000B) finds that elderly unmarried, divorced or widowed women are more likely to live alone in response to a social security reform that increased their benefits. Ardington, Case and Hosegood (2007) find in a panel data set that old-age pensions increase the labor supply of prime age male family members, in contrast to the results by Bertrand, Miller and Mullainathan (1999) in a single cross-section, and attribute it to benefits helping finance the migration of prime-aged males in search for employment.

17 In results available upon request, there was no change in elderly coresidence patterns with children under 10 or adults over 20. However, for young adults 15 to 19 of both genders, there were significant increase and decrease in coresidence with, respectively, male and female elderly benefiting from the reform.

18 Margo and Finegan (1996) presents evidence that compulsory schooling laws were effective in increasing school attendance in the United States in the beginning of the twentieth century when combined with child labor restrictions.

${ }^{19}$ Baland and Robinson (2000) make the case that child labor is an inefficient outcome of incomplete intergenerational contracting. Emerson and Souza (2007) find that adult earnings for the cohorts born in 1933 to 1971 are maximized at entry age into the labor market between 12 and 14 years old. They also argue that this peak age likely increased as the newer generations are significantly better educated than those covered in their paper.

${ }^{20}$ Shea (2000) argues that discrepancies between empirical evidence on the effects of income on children outcomes in developing and developed countries are not surprising due to higher public investments in children's health and education in developed countries. 